\title{
Examination of the Overlapping Claims of Turkey and the Greek Cypriot Administration of Southern Cyprus on the Maritime Areas to the West of the Island of Cyprus
}

\section{Berk Hasan 0zdem* (1)}

\begin{abstract}
The recent rise in tensions in the region regarding the hydrocarbons issue in the Eastern Mediterranean has two particular implications for the Republic of Turkey. One is related to the 'Cyprus issue' itself, and the other concerns the maritime areas to the west of the longitude $32^{\circ} 16^{\prime} 18^{\prime \prime}$. In the present paper, the focus is placed on the conflicting claims of Turkey and the Greek Cypriot Administration of Southern Cyprus over the maritime area off the southern Anatolian coast limited in the east by $32^{\circ} 16^{\prime} 18^{\prime \prime} \mathrm{E}$ longitude and in the south by the median line between the coasts of Turkey and Egypt. While getting to the root of the disagreement by referring back to the discussions at the Third UN Conference on the Law of the Sea on the relevant articles of the 1982 Convention, this paper addresses the issues of entitlement and delimitation by referring to judicial and arbitral decisions, the contemporary approach of the international courts, the studies that examine the state practice and the comments made by scholars thereon.
\end{abstract}

\section{Keywords}

Cyprus, Entitlement, Delimitation, Maritime, UNCLOS

Türkiye ve Güney Kıbrıs Rum Yönetimi'nin Kıbrıs Adası'nın Batısındaki Deniz Alanları Üzerindeki Çakışan Taleplerinin Incelenmesi

Öz

Güncel olarak bölgedeki gerginliği artran Doğu Akdeniz'deki hidrokarbon meselesinin Türkiye Cumhuriyeti için iki boyutu bulunmaktadır. Bunlardan biri bizatihi Kıbrıs meselesi iken; diğeri ise $32^{\circ} 16^{\prime} 18^{\prime \prime}$ boylamının batısında kalan deniz alanlarını ilgilendirmektedir. Bu çalışmada Türkiye ve Güney Kıbrıs Rum Yönetimi'nin, Anadolu'nun güney kıyısından başlayarak doğuda $32^{\circ} 16^{\prime} 18^{\prime \prime} \mathrm{D}$ boylamı ve güneyde Türkiye ile Mısır arasındaki ortay hat ile sınırlı deniz alanı üzerindeki birbiriyle çakışan talepleri üzerine yoğunlaşılmıştır. 1982 Sözleşmesi'nin ilgili maddelerine ilişkin Birleşmiş Milletler Üçüncü Deniz Hukuku Konferansı'nda gerçekleşen tartş̧malara geri dönülerek uyuşmazlı̆ıın köküne inmeye çalışılırken; mahkeme ve hakem kararlarına, uluslararası yargı mercilerinin konuyla ilgili güncel yaklaşımına, devlet pratiğini inceleyen çalışmalara ve yazarların bunlara ilişkin yorumlarına değinilerek deniz alanlarına sahip olma ve deniz alanlarının sınırlandırılması konuları ele alınmıştr.

\section{Anahtar Kelimeler}

Kıbrıs, Sahip olma, Sınırlandırma, Deniz, BMDHS

\footnotetext{
Correspondence to: Berk Hasan Ozdem (LLB), Galatasaray University, Faculty of Law, Istanbul, Turkey. E-mail: berkhasanozdem@gmail.com ORCID: 0000-0002-0327-6489

To cite this article: Ozdem BH, "Examination of the Overlapping Claims of Turkey and the Greek Cypriot Administration of Southern Cyprus on the Maritime Areas to the West of the Island of Cyprus" (2019) 77(2) İstanbul Hukuk Mecmuası 953.

https://doi.org/10.26650/mecmua.2019.77.2.0015 


\section{Examination of the Overlapping Claims of Turkey and the Greek Cypriot Administration of Southern Cyprus on the Maritime Areas to the West of the Island of Cyprus}

\section{Introduction}

Since each square meter of subsea territory may potentially contain energy resources worth millions of dollars, the exact location of maritime boundaries cannot be an issue of indifference amongst coastal neighbours in a given region. When assessing which state controls the said resources the delimitation of the maritime areas becomes undoubtedly salient. ${ }^{1}$ Nevertheless, even though international law has become more precise on the matter as time passes, practice reveals that delimitation disputes are frequently resolved only after several years. ${ }^{2}$

The case of the Eastern Mediterranean is an appropriate illustration of the fundamental role of maritime delimitation law when it comes to hydrocarbon exploration and exploitation activities. In addition to its great geopolitical and geostrategic importance in terms of military, commerce and transportation, the high potential of energy resources in the area has brought about the struggle for the delimitation of maritime areas. ${ }^{3}$

As for Turkey and Cyprus, the hydrocarbons issue in the Eastern Mediterranean has two aspects. One is related to the 'Cyprus issue' itself, and the other is the protection of Turkey's own continental shelf rights. ${ }^{4}$ The former is related to the overlapping maritime claims of the Greek Cypriot Administration of Southern Cyprus (GCASC) and the Turkish Republic of Northern Cyprus (TRNC) and to the Turkish position that Turkish Cypriots should have equal rights over the hydrocarbon resources as the co-owners of the Island. The latter, on the other hand, concerns the maritime area off the southern Anatolian coast limited in the east by $32^{\circ} 16^{\prime} 18^{\prime \prime} \mathrm{E}$ longitude and in the south by the median line between the coasts of Turkey and Egypt.

Even though the maritime areas at the west of the longitude $32^{\circ} 16^{\prime} 18^{\prime \prime}$ closely concerns multiple countries in the region such as Greece, Egypt and Libya, ${ }^{5}$ in this paper, the focus will be placed merely on the disagreement between Turkey and

\footnotetext{
Constantinos Yiallourides, 'Oil and Gas Development in Disputed Waters under UNCLOS' (2016) 5(1) UCL Journal of Law and Jurisprudence 59, 59.

2 Yoshifumi Tanaka, Predictability and Flexibility in the Law of Maritime Delimitation (Hart Publishing 2006) 125, 129-130; Yiallourides (n 1) 59.

3 Cihat Yayc1, 'Doğu Akdeniz'de Deniz Yetki Alanlarının Paylaşılması Sorunu ve Türkiye' (Bilgesam) $13<$ http://www. bilgesam.org/Images/Dokumanlar/0-159-2014040713bs-2012-1-1-70.pdf> accessed 14 August 2019.

4 Turkish Ministry of Foreign Affairs, 'Comply With The Proposal Or We Will Continue (Article by H.E. Mr. Mevlüt Çavuşoğlu, Minister of Foreign Affairs of the Republic of Turkey, published in "Kıbrıs Postası" (TRNC) on 14 July 2019)' $<$ http://www.mfa.gov.tr/disisleri-bakani-sayin-mevlut-cavusoglu_nun-kibris-postasi-gazetesinde-yayinlanan-makalesi. en.mfa $>$ accessed 14 August 2019.

5 Sami Doğru, 'Doğu Akdeniz'de Hidrokarbon Kaynakları Ve Uluslararası Hukuka Göre Bölgedeki Kıta Sahanlığı Ve Münhasır Ekonomik Bölge Alanlarının Sınırlandırılması' (2015) 119 Union of Turkish Bar Associations Review 503, 544ff.
} 
GCASC over the relevant area. Following a brief look at the legislations of both parties and their overlapping claims, the dispute will be examined more profoundly under international law.

\section{Turkish Legislation Concerning Maritime Zones}

Turkey has neither signed nor ratified the United Nations Convention on the Law of the Sea (UNCLOS). With Act No. 2674 of 20 May 1982, it sets the extension of its territorial sea at 6 nautical miles and commissions the Council of Ministers $^{6}$ to establish the breadth of the territorial sea up to a limit exceeding six nautical miles, under reservation to take into account all special circumstances and relevant situations therein, in a manner compatible with the principle of equity. ${ }^{7}$ At the moment, Turkey applies the 6-mile rule in the Aegean Sea while the limit in the Black Sea and the Mediterranean Sea is 12 nautical miles. ${ }^{8}$ Turkey has no legislation related to its continental shelf or exclusive economic zone (EEZ). ${ }^{9}$ Decree No. 86/11264 of 17 December $1986^{10}$ of Council of Ministers established the Turkish EEZ in the Black Sea at 200 nautical miles but no EEZ proclamation has been put forth for the Mediterranean or the Aegean Seas. ${ }^{11}$ Nevertheless, as for its continental shelf, Turkey signed a delimitation agreement with the Turkish Republic of Northern Cyprus in 2011 which concerned a part of its continental shelf in the Eastern Mediterranean. ${ }^{12}$

\section{GCASC Legislation Concerning Maritime Zones}

Greek Cypriot Administration of Southern Cyprus adopted the 'Territorial Sea Law' in $1964^{13}$ which declared a territorial sea of 12 nautical miles. Coordinates of this latter were submitted to the United Nations in 1993 and their validity was

\footnotetext{
With the entry of force of the Act No. 6771 dated 11 February 2017 to amend the Constitution of the Republic of Turkey, the Council of Ministers is abolished and the authorities of the Council of Ministers are transferred to the Presidency.

7 Act No. 2674 of 20 May 1982, on the Territorial Sea of the Republic of Turkey (The Division for Ocean Affairs and the Law of the Sea of the Office of Legal Affairs of the United Nations) < https://www.un.org/Depts/los/LEGISLATIONANDTREATIES/ PDFFILES/TUR_1982_Act.pdf> accessed 14 August 2019.

8 Decree by the Council of Ministers No. 8/4742 (The Division for Ocean Affairs and the Law of the Sea of the Office of Legal Affairs of the United Nations) <https://www.un.org/Depts/los/LEGISLATIONANDTREATIES/PDFFILES/TUR_1992 Decree.pdf $>$ accessed 14 August 2019.

9 Ayla Gürel, Fiona Mullen and Harry Tzimitras, The Cyprus Hydrocarbons Issue: Context, Positions and Future Scenarios, PCC Report 1/2013, (Peace Research Institute Oslo (PRIO) Cyprus Center, 2013) 19.

10 Decree by the Council of Ministers, No. 86/11264, dated 17 December 1986 (The Division for Ocean Affairs and the Law of the Sea of the Office of Legal Affairs of the United Nations) $<\mathrm{https://www.un.org/Depts/los/LEGISLATIONANDTREATIES/}$ PDFFILES/TUR_1986_Decree.pdf > accessed 14 August 2019.

11 Gürel, Mullen and Tzimitras (n 9) 19.

12 ibid 24; Mehmet Akif Kütükçü and İslam Safa Kaya, 'Uluslararası Deniz Hukuku Kapsamında Doğu Akdeniz'deki Petrol ve Doğalgaz Kaynakları ile Türkiye'nin Hukuki Durumu' (2016) 2(1) Journal of Life Sciences 81, $92 \mathrm{ff}$.

13 Territorial Waters Law, 1964 (The Division for Ocean Affairs and the Law of the Sea of the Office of Legal Affairs of the United Nations) <http://www.un.org/depts/los/LEGISLATIONANDTREATIES/PDFFILES/CYP_1964_Law.pdf> accessed 14 August 2019.
} 
reconfirmed in $1996 .{ }^{14}$ GCASC defines its continental shelf via the 'Continental Shelf Law' which was adopted in $1974 .{ }^{15}$ After ratifying UNCLOS in 1988, GCASC proclaimed an EEZ, with the enactment of the 'Exclusive Economic Zone and Continental Shelf Law' ${ }^{16}$ which was submitted to the Secretary General of the United Nations, as the depository of the UNCLOS.

According to the Exclusive Economic Zone and Continental Shelf Law which was amended ${ }^{17}$ in 2014, the outer limit of the EEZ of the GCASC is defined to a distance of 200 nautical miles from the baselines from which the breadth of the territorial sea is measured. The law states that 'in case where any part of the Exclusive Economic Zone overlaps with part of the Exclusive Economic Zone of any other State with opposite coasts to those of the Republic, the delimitation of the Exclusive Economic Zone of the Republic and the Exclusive Economic Zone of the other State shall be effected by agreement between them; in the absence of an agreement between them, the limit of the zone is the median line or the equidistance line from the respective baselines from which the breadth of the territorial sea is measured. ${ }^{18}$ The law further mentions that over its EEZ, Greek Cypriot Administration of Southern Cyprus has 'sovereign rights for the purpose of exploring, exploiting, conserving and managing the natural resources, whether living or non-living, of the waters superjacent to the seabed and of the seabed and its subsoil and with regard to other activities for the economic exploitation and exploration of the zone, such as the production of energy from the water, currents and winds. ${ }^{19}$ Through bilateral agreements it signed with Egypt, Lebanon and Israel, Greek Cypriot Administration of Southern Cyprus delimited its EEZ in the south-west, south and south-east of the Island. The provisions contained in these agreements are more or less homogeneous and in all of them, the method of median line is used to delineate boundaries. ${ }^{20}$

Following the EEZ delimitation agreement between Egypt and GCASC, Turkey put forward its arguments regarding the maritime areas of GCASC in 2003. In its information note ${ }^{21}$ submitted to UN, Turkey stated that the delimitation of EEZ or

14 Dépôt d'une carte marine et d'une liste de coordonnées géographiques par Chypre (The Division for Ocean Affairs and the Law of the Sea of the Office of Legal Affairs of the United Nations) < http://www.un.org/depts/los/LEGISLATIONANDTREATIES/ PDFFILES/mzn_s/mzn6.pdf> accessed 14 August 2019.

15 Continental Shelf Law, Law No. 8 of 5 April 1974 (The Division for Ocean Affairs and the Law of the Sea of the Office of Legal Affairs of the United Nations) <http://www.un.org/depts/los/LEGISLATIONANDTREATIES/PDFFILES/CYP_1974_Law.pdf $>$

16 A Law To Provide for the Proclamation of the Exclusive Economic Zone by the Republic of Cyprus (Law No. 64(I)/2004) (2nd April 2004) (The Division for Ocean Affairs and the Law of the Sea of the Office of Legal Affairs of the United Nations) $<\mathrm{http}: /$ www.un.org/depts/los/LEGISLATIONANDTREATIES/PDFFILES/cyp_2004_eez_proclamation.pdf> accessed 14 August 2019.

17 The Exclusive Economic Zone and the Continental Shelf Laws 2004 and 2014 (The Division for Ocean Affairs and the Law of the Sea of the Office of Legal Affairs of the United Nations) $<$ https://www.un.org/Depts/los/LEGISLATIONANDTREATIES/ PDFFILES/CYP_EEZ-CS_Law_2014.pdf> accessed 14 August 2019.

18 The Exclusive Economic Zone and the Continental Shelf Laws 2004 and 2014 (n 17) 5(b) of 97(1)/2014; See also, Sertaç Hami Başeren, Dispute Over Eastern Mediterranean Maritime Jurisdiction Areas (2010, Publications of Turkish Marine Research Foundation) 56ff.

19 The Exclusive Economic Zone and the Continental Shelf Laws 2004 and 2014 (n 17) 4(a).

20 Gürel, Mullen and Tzimitras (n 7) 14.

21 United Nations Division for Ocean Affairs and the Law of the Sea Office of Legal Affairs, Law of the Sea Bulletin 54 (New 
the continental shelf in Eastern Mediterranean, especially in areas falling beyond the western part of the longitude $32^{\circ} 16^{\prime} 18^{\prime}$ ', concerns Turkey's 'ipso facto and ab initio legal and sovereign rights', emanating from the established principles of international law. According to the Turkish Ministry of Foreign Affairs the limits of the Turkish Continental Shelf are as follows:

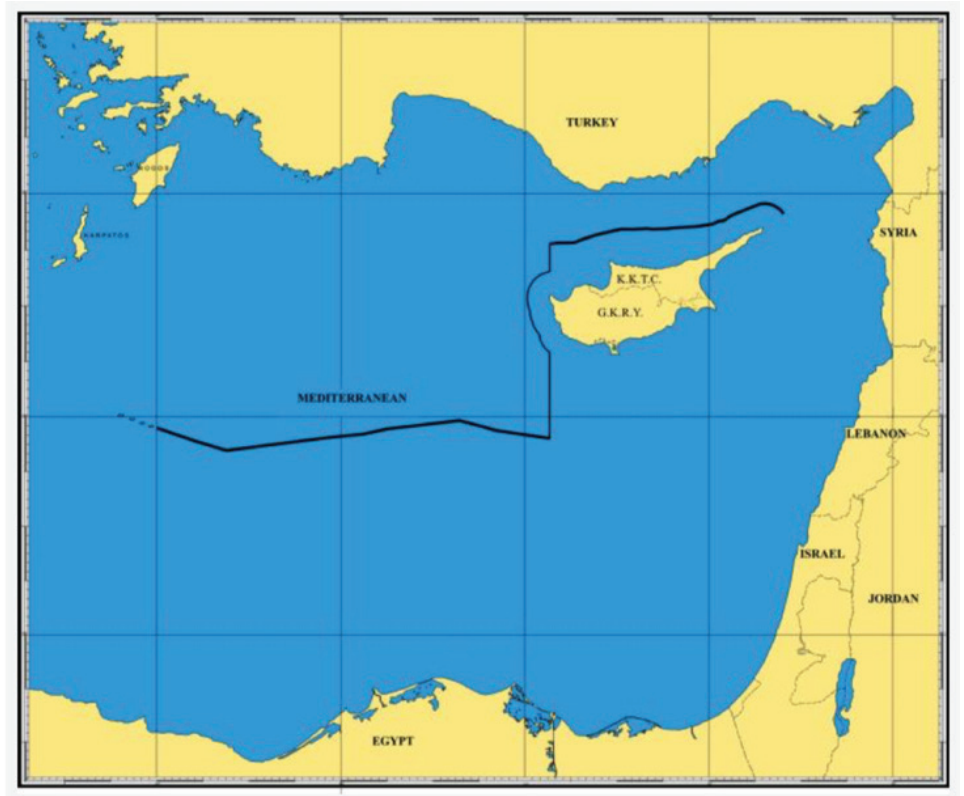

Figure 1. Turkish Continental Shelf According to the Turkish Ministry of Foreign Affairs ${ }^{22}$

In its response ${ }^{23}$ submitted to the UN, Greek Cypriot Administration of Southern Cyprus refuted Turkey's contentions stating that 'they are not based or supported by any specific legal or substantive argument'. According to GCASC, Turkey's allegation was totally unfounded since such an allegation is tantamount to accepting that the islands and even more so a sovereign island-state, namely GCASC, is deprived of any maritime zones, contrary to customary international law, UNCLOS and the rulings of the International Court of Justice (ICJ). According to the Greek Cypriot perspective, in the absence of a delimitation agreement, only claims up to the median line are acceptable. ${ }^{24}$

York, United Nations, 2004) 127.

22 Çagatay Erciyes 'Turkey's Off-Shore Activities In The Eastern Mediterranean \& Maritime Boundary Delimitation In International Law' (Turkish Ministry of Foreign Affairs, 27 May 2019) <http://www.mfa.gov.tr/site_media/html/maritimedelimitation-27-5-2019-presentation.pdf> accessed 14 August 2019.

23 United Nations Division for Ocean Affairs and the Law of the Sea Office of Legal Affairs, Law of the Sea Bulletin 57 (New York, United Nations, 2004) 124.

24 TasosTzionis 'Recentdevelopmentsinthecontinentalshelf/EEZoftheRepublicofCyprus'(MinistryofForeignAffairsofRepublic of Cyprus, 31 May 2019) < http://www.mfa.gov.cy/mfa/mfa2016.nsf/3151B8BA8E492239C225840B00415D3C/\$file/ FOR\%20WEB\%20Presentation\%20to\%20EU\%20HoMs\%2031.05.2019\%20(FINAL\%2031.05.2019)ii.pdf> accessed 14 August 2019. 


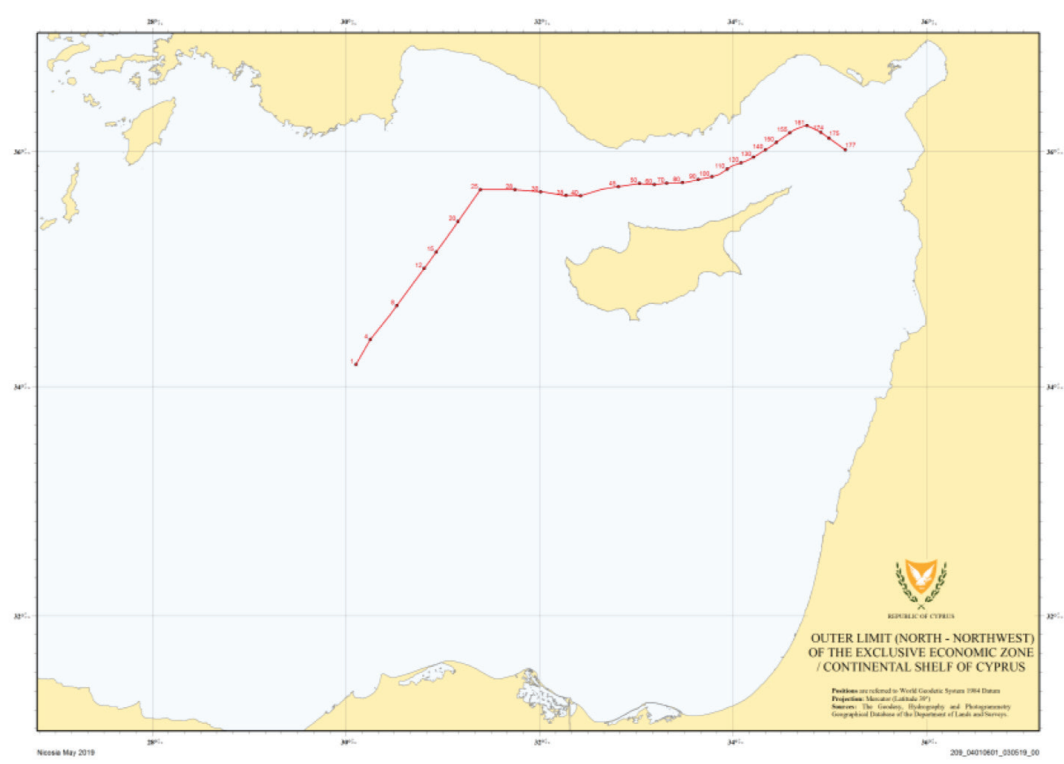

Figure 2. Coordinates of median line between Cyprus - Turkey, as deposited with the UN by the GCASC Ministry of Foreign Affairs ${ }^{25}$

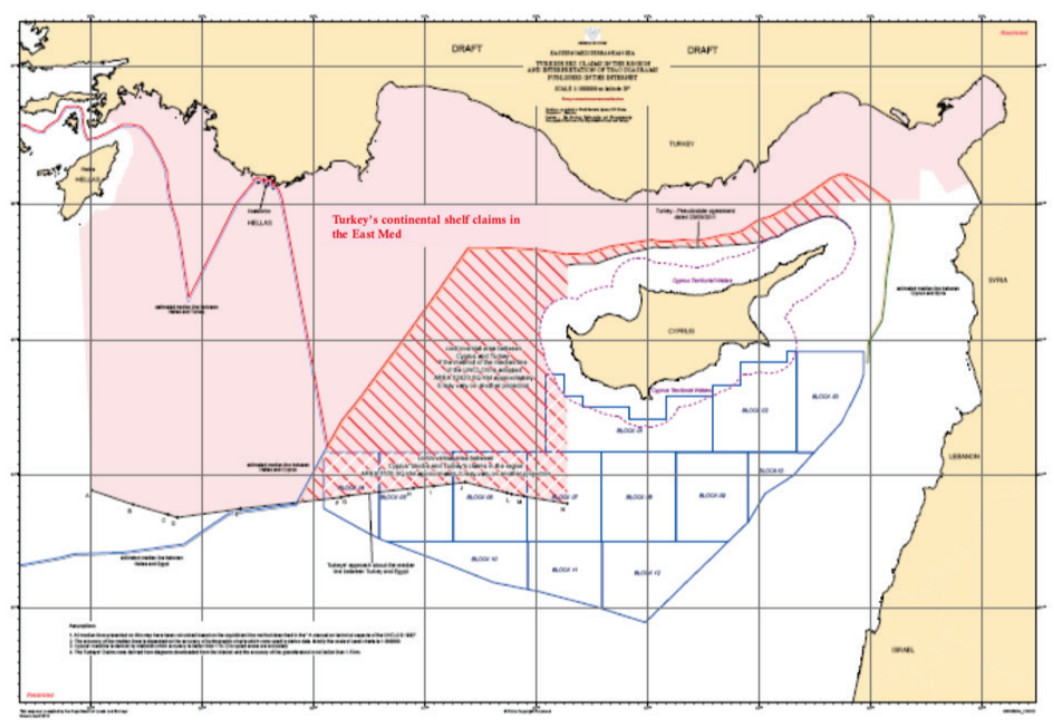

Figure 3. Overlapping Claims According to the GCASC Ministry of Foreign Affairs ${ }^{26}$ 
In 2012, Turkish Petroleum was granted licence by the Turkish Government for offshore drilling operations and the Turkish flagged drillship Fatih launched its operations on 3 May 2019. Fatih has been operating at 42 nautical miles $(75 \mathrm{~km})$ off the west coast of the Island of Cyprus where the claims of the parties overlap. ${ }^{27}$ GCASC alleged that the Turkish drilling operations are in violation of Cyprus' sovereign rights to explore and exploit the natural resources of its EEZ/continental shelf under UNCLOS and customary international law. ${ }^{28}$ Turkey, on the hand, responded to such claims as follows:

'We see that the Greek Cypriot Administration bluster in almost every platform, and put forward baseless complaints to the effect that "Turkey violates our EEZ". Why baseless? Because, with regard to the area where Fatih is drilling vessel, the maritime jurisdiction area between Turkey and the Island of Cyprus is not delimited yet through a maritime delimitation agreement. Therefore, it is not legally possible to make a definition such as "EEZ of Greek Cypriot Administration" for this area. Turkey's approach on this issue is consistent with international law. ${ }^{29}$

\section{A. Entitlement of Islands to Maritime Zones Under International Law}

As Article $121^{30}$ of UNCLOS constitutes one of the most important articles of the convention as to the maritime zones of islands, it is generally put forward in the context of the maritime disputes concerning Cyprus. ${ }^{31}$ Therefore, before dealing with the issue of delimitation, it would be beneficial to explain the concept of 'entitlement' for sake of better comprehension.

According to Turkey's longstanding position, islands, particularly in certain regions, should possess less entitlement to the zones of maritime jurisdiction than

27 Erciyes 27 May 2019 (n 22).

28 Tasos Tzionis 'Recent developments in the continental shelf/EEZ of the Republic of Cyprus' (Ministry of Foreign Affairs of RepublicofCyprus, 7June2019)<http://www.mfa.gov.cy/mfa/mfa2016.nsf/5D23B385435B9E54C2258412003676D0/\$file/

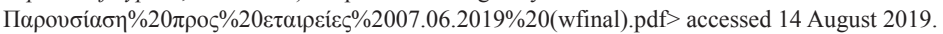

29 Turkish Ministry of Foreign Affairs 14 July 2019 (n 4).

30 United Nations Convention on the Law of the Sea of 10 December 1982, Article 121 Regime of islands

1. An island is a naturally formed area of land, surrounded by water, which is above water at high tide.

2. Except as provided for in paragraph 3, the territorial sea, the contiguous zone, the exclusive economic zone and the continental shelf of an island are determined in accordance with the provisions of this Convention applicable to other land territory.

3. Rocks which cannot sustain human habitation or economic life of their own shall have no exclusive economic zone or continental shelf.

31 See for instance, 'For the purposes of today's presentation, suffice it to say that as far as the status of islands is concerned, our position is fully safeguarded through Art. 121' Andreas Jacovides, 'Current Issues of the Law of the Sea and Their Relevance to Cyprus' (The European Rim Policy and Investment Council, 23 June 2009) $2<\mathrm{https://erpic.org/wp-content/}$ uploads/2017/02/andreas-jacovides-current-issues-of-the-law-of-the-sea-and-their-relevance-to-cyprus.pdf $>$ accessed 14 August 2019; Andreas Jacovides, 'Delimitation Practice in the Eastern Mediterranean' (The European Rim Policy and Investment Council, 25 July 2012) $4<$ https://erpic.org/wp-content/uploads/2017/02/delimitation-practice-in-the-easternmediterranean.pdf> accessed 14 August 2019;

Andreas Jacovides, International Law and Diplomacy: Selected Writings by Ambassador Andrew Jacovides (Martinus Nijhoff 2011) 92; Nikolaos Ioannidis "The Continental Shelf Delimitation Agreement Between Turkey and "TRNC" (Blog of the European Journal of International Law [EJIL], 26 May 2014) <https://www.ejiltalk.org/the-continental-shelfdelimitation-agreement-between-turkey-and-trnc/> accessed 14 August 2019; Tzionis 31 May 2019 (n 24). 
continental territories. ${ }^{32}$ This stance which resulted in the Turkish dissatisfaction ${ }^{33}$ with Article 121 of UNCLOS was one of the reasons that constrained Turkey to vote against the Convention. ${ }^{34}$

To obtain a better understanding of the position of Turkey, one must take into account the drafting history of Article 121 at the Third UN Conference on the Law of the Sea (UNCLOS III). Statements made by the delegations attending UNCLOS III disclosed highly conflicting views on the issue of islands. ${ }^{35}$ While some states supported the idea that no distinctions of any kind should be made to the extent that an island is above water at high tide, small island states argued that regardless of their size and characteristics, they must be permitted to generate an EEZ all around their islands, due to their limited land resources. ${ }^{36}$ On the other hand, it has been argued that if every island was permitted to claim an EEZ irrespective of its characteristics, states with many small uninhabited islands would receive unjust benefits and that the subject called for a distinction to be formed between islands and small islets, which will serve to exclude islets from the process of delimitation of maritime zones between neighbouring states. ${ }^{37}$ Amongst various other points of views advocated, some states were of the opinion that the entitlement of islands to maritime areas

32 In the context of the Turkish-Greek maritime dispute concerning the Aegean Sea, see for instance, Turkish Ministry of Foreign Affairs, 'The Outstanding Aegean Issues' < http://www.mfa.gov.tr/maritime-issues---aegean-sea---the-outstandingaegean-issues.en.mfa $>$ accessed 14 August 2019; Turkish Ministry of Foreign Affairs, 'Bașlıca Ege Denizi Sorunları' $<$ http://www.mfa.gov.tr/baslica-ege-denizi-sorunlari.tr.mfa > accessed 14 August 2019; Deniz Bölükbaş1, Turkey and Greece: The Aegean Disputes: a Unique Case in International Law (Cavendish, 2004) 363ff.

33 Ekrem Korkut, 'Turkey and the International Law of the Sea' (SJD Dissertations 5, The Pennsylvania State University 2017) 5-9.

34 During the Plenary Meeting 189, Ambassador Kirca from the Turkish delegation to the Third UN Conference on the Law of the Sea stated as follows: 'During the deliberations of the Conference, Turkey always stressed that the diversity of geographical circumstances was one of the most important factors to be taken into consideration in the attainment of this objective. On every occasion Turkey expressed the need to establish a proper balance between different groups of interests stemming from different geographical situations. In our view the final outcome of the Conference, as reflected in the text of the United Nations Convention on the Law of the Sea, failed to achieve such a balance. To remedy this situation and to secure universal adherence to the Convention, Turkey at the final session of the Conference proposed an amendment to the Convention which, if adopted, would have permitted reservations to the Convention. The fact that 45 States either voted in favour of that proposal or abstained indicates that a considerable number of States had difficulties with the Convention. However, in view of the rejection of this amendment and in the absence of necessary safeguards for Turkey's vital and legitimate rights and interests, Turkey was compelled to vote against the Convention, although it agreed with provisions contained in Part XI, on the international area. Consequently Turkey finds itself unable to sign the Convention.' Doc A/CONF.62/SR.189 Third United Nations Conference on the Law of the Sea 189th Plenary meeting (8 December 1982), Official Records of the Third United Nations Conference on the Law of the Sea, vol XVII, 76; Having been dissatisfied with a number of its provisions and the fact that the Treaty does not allow any reservations, Turkey did not sign or accede to UNCLOS. Nevertheless, Turkey declared its EEZs in the Black Sea and proclaimed 12 mile territorial waters in the Black Sea and Mediterranean Sea. Since Turkey has extended its territorial waters to the limit allowed by UNCLOS in the Black and in the Mediterranean Sea (12 nautical miles) yet refuses to ratify the Convention, some authors claim Turkey is preferring to treat international law 'as an a la carte menu.' Yiorghos Leventis, 'Projecting for Control of Warm Waters. Turkey's Posturing for Hydrocarbon Hegemony in the Eastern Mediterranean' in Hubert Faustmann, Ayla Gürel and Gregory M. Reichberg (eds), The Hydrocarbon Wealth of Cyprus: Equitable Distribution and Regional Politics (Peace Research Institute Oslo (PRIO) Cyprus Center/Friedrich Ebert Foundation 2012) 7, 11-14; Jacovides 25 July 2012 (n 31) 5.

35 See generally, United Nations Division for Ocean Affairs and the Law of the Sea, Régime of Islands: Legislative History of Part VIII (Article 121) of the United Nations convention on the Law of the Sea (1988, United Nations).

36 Robert Beckman and Clive Schofield, 'Moving Beyond Disputes Over Island Sovereignty: ICJ Decision Sets Stage for Maritime Boundary Delimitation in the Singapore Strait' (2009) 40(1) Ocean Development \& International Law 1, 9.

37 Beckman and Schofield (n 36) 9 . 
should depend on both geographical and non-geographical criteria. ${ }^{38}$ Some others contended that it would be nothing but impossible to establish a rule which offers fair results in each and every occasion no matter how unique the geographical situation could be. ${ }^{39}$

The issue of maritime zones of the islands was an 'apple of discord' ${ }^{40}$ between the delegation of Turkey and the delegations of Greece and Cyprus during UNCLOS III. According to Andreas Jacovides, head of the Greek Cypriot delegation, one of the main objectives of his delegation during the conference was to ensure that islands are in the same position as continental territories in terms of entitlement to the zones of maritime jurisdiction including territorial sea, contiguous zone, exclusive economic zone and the continental shelf. ${ }^{41}$ In opposition, Turkey argued that for such entitlement, account should be taken of issues such as the size, population, geographical and geomorphological characteristics (such as contiguity to principal territory or being located on the continental shelf of another state) of the island and so forth. ${ }^{42}$

Until the conclusion at Montego Bay in December 1982, Turkey's objection to the a priori entitlement of islands to maritime zones was clear from the beginning to the end. At the early stage, when the Greek Government submitted to the Conference its "Draft Articles on the Regime of Islands and Other Matters" ${ }^{\text {"43 }}$ which granted islands the entitlement to have continental shelves, contiguous zones and economic zones without reference to any kind of factors or special circumstances, Turkey responded by coming up with its own draft. ${ }^{44}$ Submitted to the UNCLOS III on 13 August 1974, Article 3(3) of the Turkish "Draft Articles on the Régime of Islands" 45 provided as follows: bed and the subsoil thereof and to the continental shelf for the purpose of exploring it and exploiting its natural resources. 3. The island has a contiguous zone and an economic zone on the same basis as the continental territory, in accordance with the provisions of this Convention. Doc A/CONF.62/C.2/L.50 Third United Nations Conference on the Law of the Sea, Greece: draft articles on the regime of islands and other related matters (9 August 1974), Official Records of the Third United Nations Conference on the Law of the Sea, vol III, 227.

44 Emmanuel Roucounas, 'Greece and the Law of the Sea', in Tullio Treves, Laura Pineschi (eds), The Law of the Sea (Kluwer, 1997) $225,231$.

45 The Draft Articles were submitted only four days after the submission of the Greek Draft Articles. Doc A/CONF.62/C.2/L.55 Third United Nations Conference on the Law of the Sea, Turkey: draft articles on the regime of islands (13 August 1974), Official Records of the Third United Nations Conference on the Law of the Sea, vol III, 230.
} 
'An island situated in the economic zone or on the continental shelf of other States shall have no economic zone or continental shelf of its own if it does not contain at least one tenth of the land area and population of the State to which it belongs. ${ }^{46}$

While the Conference was going on, the Turkish position was reiterated in 1976 in the context of the Aegean Sea Continental Shelf (Greece v. Turkey) ${ }^{47}$ dispute which concerned the sovereignty over the maritime zones in the Aegean Sea. In the said case, Turkey defended the idea that islands should not be entitled to have continental shelves of their own should they be situated on the continental shelf of a land and constitute a natural prolongation of the latter. ${ }^{48}$ This argument was based on the judgment of the ICJ in the North Sea Continental Shelf Cases ${ }^{49}$ by taking that natural prolongation in a geomorphologic sense establishes the source of the rights over the continental shelf. ${ }^{50}$ According to Turkey, the geological data put forth that the continental shelf of the Turkish mainland of Anatolia extended under the Aegean Sea in geomorphologic terms up to the discontinuity around midway between the principal territories. ${ }^{51}$

In 1978, when the provisions of Article 121 had already been incorporated in their present form into the 'Informal Composite Negotiating Text', Turkey and nine other States suggested a new draft article on the regime of islands which was considered to be 'less-far reaching'. ${ }^{52}$ Provided as follows, the draft article allowed islands to have marine spaces until the point that it would be contrary to equity:

46 See also, Alex G Oude Elferink, The law of maritime boundary delimitation: a case study of the Russian Federation (Martinus Nijhoff Publishers 1994) 288ff.

47 'The basic question in dispute is whether or not certain islands under Greek sovereignty are entitled to a continental shelf of their own and entitle Greece to call for the boundary to be drawn between those islands and the Turkish Coast?' Aegean Sea Continental Shelf (Greece v. Turkey), [1978] ICJ Rep 3 [83].

48 Turkish Ministry of Foreign Affairs, The Outstanding Aegean Issues (n 32). Statement of Turkish Position by Ambassador Bilge on 31 January 1976 was as follows: 'Our position is based on the view that the continental shelf in international law is the natural prolongation of the land territory of the coastal state into and under the sea...' ICJ Pleadings, Aegean Sea Continental Shelf (Greece v. Turkey) 167, 168; Bölükbaș1 (n 32) 152ff.

49 'In the present case, although both sides relied on the prolongation principle and regarded it as fundamental, they interpreted it quite differently. Both interpretations appear to the Court to be incorrect. Denmark and the Netherlands identified natural prolongation with closest proximity and therefrom argued that it called for an equidistance line: the Federal Republic seemed to think it implied the notion of the just and equitable share, although the connection is distinctly remote. (The Federal Republic did however invoke another idea, namely that of the proportionality of a State's continental shelf area to the length of its coastline, which obviously does have an intimate connection with the prolongation principle, and will be considered in its place.) As regards equidistance, it clearly cannot be identified with the notion of natural prolongation or extension, since, as has already been stated (paragraph 8), the use of the equidistance method would frequently cause areas which are the natural prolongation or extension of the territory of one State to be attributed to another, when the configuration of the latter's coast makes the equidistance line swing out laterally across the former's coastal front, cutting it off from areas situated directly before that front ...' North Sea Continental Shelf (Federal Republic of Germany/Denmark), [1969] ICJ Rep 3 [44]; ' $\ldots$ for the reasons given in paragraphs 43 and 44, the continental shelf of any State must be the natural prolongation of its land territory and must not encroach upon what is the natural prolongation of the territory of another State.' North Sea Continental Shelf (n 49) [85].

50 See, Yüksel İnan and Yücel Acer, 'The Aegean disputes' in Ali L. Karaosmanoğlu and Seyfi Tașhan (eds), The Europeanization of Turkey's security policy: Prospects and pitfalls (Turkish Foreign Policy Institute 2004) 125, note 124; See, the statement of Turkish representative Mr. Yolga at Official Records of the Third United Nations Conference on the Law of the Sea, vol I, 168-170.

51 See, Section of Geological Data of Turkish Position during the Bern Meeting as Dictated by Professor Arpat. 2 February 1976, in, Pleadings, Aegean Sea Continental Shelf (n 48) 169.

$52 \quad$ See also, Oude Elferink 1994 (n 46) 289. 
"Islands which because of their geographical location constitute a source of distortion or inequity in the drawing of a boundary line between two or more adjacent or opposite States shall have marine spaces only to the extent compatible with equitable principles and with all geographic and other relevant circumstances." ${ }^{53}$

Following the Judgment of Aegean Sea Continental Shelf delivered on 19 December 1978 where the ICJ found that jurisdiction was not conferred upon it to deal with the dispute, the dissatisfaction of Turkey due to the regime of islands was once again repeated near the end of the Conference. During the 160th plenary meeting, Ambassador Kirca from the Turkish delegation stated that 'Article 121 (Regime of islands) was unacceptable in its present form' ${ }^{54}$

Despite many efforts to withhold some islands from entitlement to the maritime areas, in the end, the Conference limited itself merely to the exclusion of those that are rocks and cannot sustain human habitation or economic life. ${ }^{55}$ According to Jacovides, following the hard-fight over its adoption, Article 121 represented the achievement of the Greek Cypriot objective concerning the regime of islands. ${ }^{56}$ During the 189th Plenary Session, Jacovides had expressed the contentment of the Cypriot delegation with the following words:

'As an island State, in common with other island States and States which consist of continental and insular territory, we have argued strenuously against the attempt to discriminate against and diminish the position of islands by creating artificially novel distinctions based on legally untenable considerations such as size, population, geographical location, and so forth. Therefore we are fully satisfied with the Convention's provision. ${ }^{57}$

According to Jacovides, the principle reflected in Article 121 regarding the entitlement of the islands to the same rights as continental territories in the context of maritime areas was the result of 'a process of compromise and consensus' and constituted an example of 'the retention of those positive rules of traditional international law which have stood the test of time and have served well the needs of the international community'. ${ }^{58}$ Although Article 121 definitely did not result from a process of 'consensus' taking into account numerous objections ${ }^{59}$ made inter alia by

53 Doc C.2/Informal Meeting/21 of 28 April 1978, informal suggestion by Algeria, Bangladesh, Cameroon, Iraq, Libya, Madagaskar, Morocco, Nicaragua, Somalia and Turkey; Barbara Kwiatkowska and Alfred HA Soons, 'Entitlement to Maritime Areas of Rocks Which Cannot Sustain Human Habitation or Economic Life of Their Own' (1990) 21 Netherlands Yearbook of International Law 139, 159

${ }^{54}$ Doc A/CONF.62/SR.160 Third United Nations Conference on the Law of the Sea 160th Plenary meeting (30 March 1982), Official Records of the Third United Nations Conference on the Law of the Sea, vol XVI, 27.

55 İnan and Acer (n 50) 98; For various phases of the Conference see generally, United Nations Division for Ocean Affairs and the Law of the Sea, Régime of Islands (n 35).

56 Jacovides 25 July 2012 (n 31) 2.

57 189th Plenary meeting (8 December 1982) (n 34) 70-71.

58 ibid 70.

59 According to the Turkish delegation 'The present text of the convention was clearly far from being the result of a consensus'. Doc A/CONF.62/SR.169 Third United Nations Conference on the Law of the Sea 169th Plenary meeting (15 April 1982), Official Records of the Third United Nations Conference on the Law of the Sea, vol XVII, 96; During the 
the Turkish delegation, Jacovides was not wrong in terms of the customary character that Article 121 of UNCLOS reflected. Notwithstanding the fact that Turkey did not sign or accede to UNCLOS, GCASC states that Article 121 constitutes a reflection of the customary law and, accordingly, applies to non-states parties as well. ${ }^{60}$ This argument is based on the ICJ Judgment in the Case Concerning Maritime Delimitation and Territorial Questions Between Qatar and Bahrain where the Court noted that:

'In accordance with Article 121, paragraph 2, of the 1982 Convention on the Law of the Sea, which reflects customary international law, islands, regardless of their size, in this respect enjoy the same status, and therefore generate the same maritime rights, as other land territory. ${ }^{61}$

The customary characteristic of Article 121 paragraph 2 of UNCLOS was reiterated by the ICJ in its Judgment on Territorial and Maritime Dispute (Nicaragua v. Colombia) where it was stated that:

'The Court has recognized that the principles of maritime delimitation enshrined in Articles 74 and 83 reflect customary international law [...]. In the same case it treated the legal definition of an island embodied in Article 121, paragraph 1, as part of customary international law [...]. It reached the same conclusion as regards Article 121, paragraph 2 [...]. The Court therefore considers that the legal régime of islands set out in UNCLOS Article 121 forms an indivisible régime, all of which [...] has the status of customary international law. ${ }^{62}$

Nevertheless, the authors mention that the rules of customary law reflecting these principles cannot be applied to Turkey since Turkey has persistently objected to the Articles of UNCLOS related to the regime of islands. ${ }^{63}$ This argument is based on

Plenary Meeting 189, Ambassador Kurca stated as follows: 'We had intended to sign the Final Act if it had not been drafted in its present language, which prejudices the position of Turkey on the Convention. The sentence added to paragraph 41, which reads, "Throughout the preceding eight years of its work the Conference had taken all decisions by consensus..." $[A]$ CONF.62/121], not only creates a misleading impression of the proceedings of the Conference but also presents serious difficulties for us. It is a well-known fact that at both the formal and the informal meetings of the Conference the Turkish delegations expressly raised objections to a number of articles and submitted amendments thereto, and never gave their consent to those which did not accommodate the Turkish views.' 189th Plenary meeting (n 34) 76.

60 Tzionis 7 June 2019 (n 28); See generally for the impacts of UNCLOS on the non party, Luke T Lee 'The Law of the Sea Convention and Third States' (1983) 77 The American Journal of International Law 541.

${ }_{61}$ Maritime Delimitation and Territorial Questions between Qatar and Bahrain (Qatar v. Bahrain) [2001] Merits, Judgment, ICJ Rep 40, [185].

62 Territorial and Maritime Dispute (Nicaragua v. Colombia) [2012] Merits, Judgment, ICJ Rep 624, [139]; See, Valérie Boré Eveno, 'L'interprétation de l'article 121 de la Convention des Nations Unies sur le droit de la mer par la Cour internationale de Justice' in Angela Del Vecchio, Roberto Virzo (eds), Interpretations of the United Nations Convention on the Law of the Sea by International Courts and Tribunals. (2019 Springer) 59, 60ff.

${ }_{63}$ 'Turkey refuses to sign and ratify the said convention. She is also a persistent objector to the rules of UNCLOS regarding the delimitation of maritime zones and the islands having maritime zones etc.' Ulaş Gündüzler, 'United Nations Convention on Law of Sea as a Mixed Treaty of EU: A Headache for Turkey?' (2013) 12(2) Ankara Avrupa Çalışmaları Dergisi 61, 64; İsmail Demir, 'Montrö Boğazlar Sözleşmesi'nin Feshi' (2018) 136 Union of Turkish Bar Associations Review 327, 345; In the context of territorial waters, Melih Başdemir, 'Türkiye'nin Avrupa Birliği Müzakere Sürecinde Yunanistan ile Olan Karasuları Sorunu' (2007) 6 Güvenlik Stratejileri Dergisi 93, 108; Şule Anlar Güneş, 'Birleşmiş Milletler Deniz Hukuku Sözleşmesi ve Deniz Çevresinin Korunması' (2007) 56(1) Ankara Üniversitesi Hukuk Fakültesi Dergisi 1, 12; Cem Gürdeniz, 'Jeopolitik, Savunma ve Güvenlik Perspektifinde Türk Deniz Gücü ve 21nci Yüzyıl' (21. Yüzyıl İçin Planlama) $9<$ http://21 inciyuzyilicinplanlama.org/wp-content/uploads/2016/08/Cem-Gurdeniz-4.-Sunum.pdf $>$ accessed 14 August 2019. Turkey is the only state to vote against the annual omnibus resolutions of the UN General Assembly of the Law of the Sea calling upon States that have not acceeded to the 1982 Convention to become parties to UNCLOS. For instance, in 2019, the draft resolution on "Oceans and the law of the sea" (A/73/L.35), was adopted with 121 votes in favour, 1 against (Turkey) and 3 abstentions (Colombia, El Salvador, Venezuela). 
the concept of the 'persistent objector rule' which dictates that even though the rules of customary international law 'by their very nature, must have equal force for all members of the international community, and cannot therefore be the subject of any right of unilateral exclusion exercisable at will by any one of them in its own favour', ${ }^{64}$ a State which has persistently objected to a rule of customary international law during its stage of emerging, and maintains its objection after the rule's crystallization, can prevent the rule from becoming binding on it. ${ }^{65}$

The concept of persistent objector is predominantly advocated by writers standing by the 'voluntarist' theory of international law which depends on the presumption that the very establishment of international law is based on the will of sovereign States and that a State must be bound only by the law to which it has itself consented. ${ }^{66}$ As Tesón notes 'By emphasizing states' consent, the theory serves as a reminder that international law is a human creation, a device contrived by men and women to solve human problems, and hence that every nation should have its say in what the rules should be' ${ }^{67}$ The concept of persistent objector has been regarded as 'the clearest, most firmly established expression of voluntarist conception of obligation in the accepted doctrines of sources' ${ }^{68}$ Another supporter of the concept has even expressed that 'it is this opportunity for each individual State to opt out of a customary rule that constitutes the acid test of custom's voluntarist nature'. ${ }^{69}$

The classic formulation of the voluntarist theory was set out in the well-known Lotus case where the Permanent Court of International Justice noted that 'The rules of law binding upon states [...] emanate from their own free will as expressed in conventions or by usages generally accepted as expressing principles of law. ${ }^{70}$ In fact, if one has a flashback to the negotiations at UNCLOS III, it is seen that the statements of Ambassador Kirca that relate to Turkey's disavowment of the relevant Articles and to the inapplicability of these latter to Turkey as customary international law, exactly reflect the principle underscored in the Lotus case which adheres to the theory of voluntarism:

${ }_{64}$ North Sea Continental Shelf (n 49) [63].

65 Doc. A/CN.4/682 International Law Commission, Third Report on Identification of Customary International Law (prepared by Special Rapporteur Michael Wood) (Geneva, Sixty-seventh session 27 March 2015) 59.

${ }_{66}$ International Law Association Committee on Formation of Customary (General) International Law, Statement of Principles Applicable to the Formation of General Customary International Law (International Law Association, London Conference 2000) 27; Patrick Dumberry, 'The Last Citadel! Can a State Claim the Status of Persistent Objector to Prevent the Application of a Rule of Customary International Law in Investor-State Arbitration?' (2010) 23 Leiden Journal of International Law 379, 389.

67 Fernando R. Tesón, 'International Obligation and the Theory of Hypothetical Consent', (1990) 15 Yale Journal of International Law 84, 97.

68 Ted Stein, 'The Approach of the Different Drummer: the Principle of the Persistent Objector in International Law', (1985) 26 Harvard International Law Journal 457, 470.

69 Prosper Weil, 'Towards Relative Normativity in International Law?' (1983) 77 American Journal of International Law 413, 433-434; See also generally I. M. Lobo de Souza, "The Role of State Consent in the Customary Process" (1995) 44 International and Comparative Law Quarterly 521.

70 Lotus Case (France v Turkey) PCIJ Rep Series A No 10, 18; Patrick Dumberry, 'Incoherent and Ineffective: The Concept of Persistent Objector Revisited' (2010) 59 International and Comparative Law Quarterly 779, 795. 
'International custom depends on the consent of States and it is a rule of international law that a State may contract out of a custom in the process of formation. ${ }^{71}$

'It is a well-known fact that at both the formal and the informal meetings of the Conference the Turkish delegations expressly raised objections to a number of articles and submitted amendments thereto, and never gave their consent to those which did not accommodate the Turkish views.' ${ }^{72}$

'Article 121 (Regime of islands) was unacceptable in its present form and his country maintained its right to reserve its position on that. ${ }^{13}$

'... we solemnly declare that this treaty can in no way be applied against Turkey, nor would Turkey be bound by any one of its provisions, since such claims would have no juridical validity. ${ }^{74}$

Nevertheless, although the conceptual role of the rule may be interpreted straightforwardly as a reflection of the fundamentalist positivist notion that any norm of international law can only bind a state that has consented to be bound by it and accordingly that 'a State can prevent a rule of customary law becoming binding on it in the first place', ${ }^{75}$ it must be mentioned that unanswered questions still exist as to the existence of this rule that provides states with an 'escape hatch'76 from the universal binding force of customary international law. ${ }^{77}$ In this regard, it may be helpful to have a brief look at the recent reports ${ }^{78}$ of the International Law Commission of United Nations (ILC) who has a reciprocal relationship with the ICJ in which both groups reiterate each other's positions. ${ }^{79}$ In its report, ILC mentions that in spite

71 189 th Plenary meeting (n 34) 76.

72 ibid

73 160th Plenary meeting (30 March 1982) (n 54) 27; United Nations Division for Ocean Affairs and the Law of the Sea, Régime of Islands (n 35) 103.

74 189th Plenary meeting (8 December 1982) (n 34) 78.

75 Ian Brownlie, Principles of Public International Law (2003, 4th edn, Oxford University Press) 10-11.

76 James A. Green, Persistent Objector Rule in International Law (Oxford University Press 2018) 189.

77 'Plenty of writers doubt whether the persistent objector rule exists at all and see it as a mere academic fiction, while others - although accepting the rule's existence per se - argue that it both is theoretically incoherent and has extremely limited utility within the modern international legal system.' ibid 5 .

78 Doc A/73/10 International Law Commission, Report of the International Law Commission (Seventieth session 30 April-1 June and 2 July-10 August 2018); International Law Commission (n 65).

79 Leo Park, 'The International Court and Rule-Making: Finding Effectiveness' [2018] 39(4) University of Pennsylvania Journal of International Law 1065, 1080; See also, Rosalyn Higgins, 'President, International Court of Justice, Keynote Address at the Sixtieth Anniversary of the International Law Commission (May 19, 2008)' Statements by the President, International Court of Justice; For instance, according to Crawford, as of 2013, the 'Articles on State Responsibility of States for Internationally Wrongful Acts' which is adopted by the Commission have been cited in over 150 international tribunals. It is therefore stated that, the ILC provides an important avenue through which the Court's decisions can exert considerable influence. James Crawford, 'The International Court of Justice and the Law of State Responsibility', in Christian Tams and James Sloan (eds), The Development of Law by the International Court of Justice (Oxford University Press 2013) 71, 81; To better understand the relationship between the ICJ and the ILC, a brief from the North Sea Continental Shelf may be useful where following the rejection of the claims of both parties, the Court took into account the fact that the principle of equidistance (which will be explained below) as codified in Article 6 of the 1958 Geneva Convention on the Continental Shelf, had not been proposed by the International Law Commission as an emerging rule of customary international law: "In the records of the International Law Commission, which had the matter under consideration from 1950 to 1956, there is no indication at all that any of its members supposed that it was incumbent on the Commission to adopt a rule of equidistance because this gave expression to, and translated into linear terms, a principle of proximity inherent in the basic concept of the continental shelf, causing every part of the shelf to appertain to the nearest coastal State and to no other, and because 
of authors ${ }^{80}$ who question its existence, the persistent objector rule is not seldom referred to and recognized both in international and domestic case law as well as in other contexts. ${ }^{81}$ Moreover, aside from a measure of judicial and arbitral support for the existence of the rule, as emphasized by the International Law Association in its 'London Statement' in 2000 and restated by the International Law Commission in 2015, 'there are no decisions that challenge it.' ${ }^{82}$ The Commission affirms that the persistent objector rule is a widely accepted element of current international law by States and writers as well as by scientific bodies engaged in international law. ${ }^{83}$

such a rule must therefore be mandatory as a matter of customary international law. Such an idea does not seem ever to have been propounded. Had it been, and had it had the self-evident character contended for by Denmark and the Netherlands, the Commission would have had no alternative but to adopt it, and its long continued hesitations over this matter would be incomprehensible." North Sea Continental Shelf (n 49) [49].

80 See for instance, Anthony D'Amato, The Concept of Custom in International Law (1973 NCROL) 233-263; Omar Abasheikh, 'The Validity of the Persistent Offender Rule in International Law' (2004) 9 Coventry Law Journal 40, 44; Curtis A. Bradley \& Mitu Gulati, 'Withdrawing from International Custom' (2010) 120 Yale Law Journal 202, 213; Holning Lau, 'Rethinking the Persistent Objector Doctrine in International Human Rights Law' (2005-2006) 6 Chicago Journal of International Law 495, 495-498, and 504-505; Brian D. Lepard, Customary International Law: A New Theory with Practical Applications (Cambridge University Press 2010) 7 and 38; Ademola Abass, Complete International Law: Text, Cases, and Materials (2nd edn, Oxford University Press 2014), 48; See generally, Stein (n 68) 457; Jonathan I. Charney, 'The Persistent Objector Rule and the Development of Customary International Law' (1985) 56 British Yearbook of International Law 1.

${ }_{81}$ Report of the International Law Commission (Seventieth session) 153; See, for example, Fisheries case (United Kingdom v. Norway) Judgment of December 18th [1951] ICJ Rep 116, 131; Michael Domingues v. United States (Case 12.285), Report No. 62/02, Inter-American Commission on Human Rights, Doc. 5 rev. 1 at 913 (2002) [48], [49]; Roach \& Pinkerton v. United States (Case 9647) Inter-American Commission on Human Rights 147, OEA/ser.LJV/II.71, doc. 9 rev. 1 (1987) [168]; Sabeh El Leil v. France [GC], No. 34869/05, European Court of Human Rights, 29 June 2011 [54]; Fischbach \& Friedricy case, 10 RIAA 388, (1903, Germany-Venezuela Mixed Claims Commission) 397; Siderman de Blake v. Republic of Argentina, United States Court of Appeals for the Ninth Circuit, 965 F.2d 699; 1992 U.S. App., [54]; For a detailed analysis of the concept in case law and state practice see, Green (n 76) 21-59; For the practice of US related to the concept see, Dumberry (n 70) 789-790.

82 International Law Association Committee on Formation of Customary (General) International Law (n 66) 27; International Law Commission (n 65) 59.

83 Report of the International Law Commission (Seventieth session) (n 78) 153; International Law Association Committee on Formation of Customary (General) International Law (n 66) 27ff; See for instance, Gerald Fitzmaurice, 'The Law and Procedure of the International Court of Justice, 1951-54: General Principles and Sources of Law' (1953) 30 British Yearbook of International Law 1, 21-26; J. Brock McClane, 'How Late in the Emergence of a Norm of Customary International Law May a Persistent Objector Object?' (1989) 13 ILSA Journal of International Law 1, 6; Mark E Villiger, Customary International Law \& Treaties (2nd edn, Brill Nijhoff 1997) 33-37; Karol Wolfke, Custom in Present International Law (2nd edn, Martinus Nijhoff 1993) 66-67; Robert Jennings and Arthur Watts (eds), Oppenheim's International Law, I: Peace (9th edn, Oxford University Press 1992) 29; Charles Rousseau, Droit international public, I (Sirey 1970) 326; Jan Hendrik Willem Verzijl, International Law in Historical Perspective, I (Albertus Willem Sijthoff 1968) 37; Brownlie (n 75) 10ff; Louis Henkin, 'International Law: Politics, Values and Function: General Course on Public International Law' (1989) 216 Recueil des cours 53-58; Prosper Weil, 'Le droit international en quête de son identité: Cours général de droit international public' (1992) 237 Recueil des cours 196-197; Gennadii Mikhaĭlovich Danilenko, Law-Making in the International Community (Brill Nijhoff 1993) 109-113; See, Green (n 76) 23-27; See, Dumberry (n 70) note 35; The text of the draft conclusions on identification of customary international law adopted by the Commission at its seventieth session provides as follows: Conclusion 15 Persistent objector 1 . Where a State has objected to a rule of customary international law while that rule was in the process of formation, the rule is not opposable to the State concerned for so long as it maintains its objection. 2 . The objection must be clearly expressed, made known to other States, and maintained persistently. 3 . The present draft conclusion is without prejudice to any question concerning peremptory norms of general international law (jus cogens). Report of the International Law Commission (Seventieth session) (n 78) 121; The Special Rapporteur for the International Law Commission, Sir Michael Wood, shares his thoughts on the concept of persistent objector as follows: 'The matter was not without controversy within the Commission in 2015. Some questioned the inclusion of the draft conclusion, either on the ground that it did not really have a place in a topic that was concerned with the identification of rules of customary international law, or-more radically-because they were not convinced that the persistent objector rule formed part of international law. Still others seem to have felt that the rule was too rarely invoked and too exceptional to justify inclusion in the draft conclusions. Others, however, agreed with my view, as Special Rapporteur, that draft conclusion 15 did have a place in the text, that the rule was well established in international law, that it arose in practice rather more frequently than is commonly supposed (including before a wide range of international and domestic courts and tribunals), and that it was therefore important to spell out the stringent requirements for its application. It was also pointed out that the Commission had acknowledged the existence of the rule as recently as 2011 in its Guide to practice on reservations to treaties.' Foreword by Sir Michael Wood in Green (n 76) viii. 
When addressing the ICJ's stance on the issue of persistent objector in the context of general customary law, the Anglo Norwegian Fisheries ${ }^{84}$ case is often referred to. The case concerned, inter alia, the validity of methods used to delimit Norway's territorial zone under international law, following the seizure of a number of British ships by Norway. With a proclamation from 1935 made by the King of Norway, the latter had already declared its own conventional system of delimitation (the method of 'straight lines') which it used for territorial seas or fisheries zones in the Arctic Circle region off its northern coast. Repudiating the Norwegian method, the United Kingdom, only acknowledged the authenticity of the said method for 'historical bays' and contended that a different method of delimitation (the 'ten miles rule') had been considered as customary law for all other cases. Both states made mention of the persistent objector rule in their respective pleadings. ${ }^{85}$ Even though the ICJ noted in its judgment that the ten-miles rule had not attained the status of custom, it held that '[i]n any event the ten-miles rule would appear to be inapplicable as against Norway inasmuch as she always opposed any attempt to apply it to the Norwegian coast. ${ }^{86}$

Another case of ICJ which appears to support the concept is sylum ${ }^{87}$ where the dispute arose after a Colombian embassy granted asylum to a Peruvian national as a political refugee. The question before the Court was whether Colombia was unilaterally competent to define the offense as 'political' for which the Peruvian national sought refuge. The court touched on the concept of persistent objector while dealing with a treaty which Colombia cited in favour of its argument. According to the Court, given the fact that Peru had not only failed to ratify the treaty in question, but also had specifically rejected its provisions regarding asylum, these latter could not be invoked against Peru even if they represented the customary law. The Court stated that it could not:

"[...] find that the Colombian Government has proved the existence of such a custom. But even if it could be supposed that such a custom existed between certain Latin-American States only, it could not be invoked against Peru which, far from having by its attitude adhered to it, has, on the contrary, repudiated it by refraining from ratifying the Montevideo Conventions of 1933 and 1939, which were the first to include [the rule in question]." ${ }^{\prime 8}$

\footnotetext{
Fisheries case (n 81) 116.

85 ICJ Pleadings, Fisheries case (United Kingdom v. Norway) vol I 382-383 (Norway); vol II, 428-429 (United Kingdom); vol III, 291-296 (Norway); See also, Dumberry (n 70) 785.

86 Fisheries case (n 81) 131.

87 Colombian-Peruvian asylum case (Colombia v. Peru) Judgment of November 20th [1950] ICJ Rep 266,

88 Colombian-Peruvian asylum case (n 87) 277; Those who advocate for the concept of persistent objector moreover cite separate or dissenting opinions voiced in ICJ decisions. See, for instance the Colombian-Peruvian asylum case (Colombia v. Peru) Judgment of November 20th [1950] ICJ Rep, dissenting opinion of Judge Azevedo (336-337); South West Africa Case, Second Phase (Ethiopia v South Africa, Liberia v South Africa) [1966] ICJ Rep, separate opinion of Judge Van Wyk (169-170); North Sea Continental Shelf (Federal Republic of Germany/Denmark), [1969] ICJ Rep, separate opinion of Judge Ammoun (130-131), dissenting opinions of Judge Lachs (238) and Judge Sorensen (247-248); Nuclear Tests Case (Australia v France) [1974] ICJ Rep, separate opinion of Judge Gros (286-289).
} 
Hereof, it must be pointed out that, as Green notes ${ }^{89}$, in many works written by scholars which address the aforementioned concept, the importance is placed upon the criteria of consistency rather than (or in addition) to the requirement of persistence. ${ }^{90}$ These two terms are remarkably disparate as the term 'persistence' embodies repetition and steadfastness whereas the term 'consistency' implicates 'non-derogation' by the state from its dissenting position. A state may in fact repeatedly and constantly object to an emerging law, yet affirm the same norm in few-and-far-between cases despite its everlasting policy of objection. This would mean that the state is persistently but inconsistently objecting to the norm in question.

With regard to the maritime areas at the west of the longitude $32^{\circ} 16^{\prime} 18^{\prime \prime}$ and the Turkish objection to the a priori entitlement of islands to maritime zones, the Greek Cypriot Administration of Southern Cyprus contends that Turkey cannot opine to be in the position of persistent objector. This stance was implied by the Greek Cypriot government in its response to the information note of Turkey ${ }^{91}$ which was submitted to the UN and concerned the objection of Turkey to the delimitation agreement signed between Egypt and GCASC in 2003. GCASC states that it submitted a Law in $1974^{92}$ proclaiming its Continental Shelf and in May 1993 a set of coordinates and a chart ${ }^{93}$ depicting its baselines to the United Nations Division for Ocean Affairs and the Law of the Sea, without any objection on behalf of Turkey. According to GCASC, such practice amounts to tacit recognition of the entitlement of the Greek Cypriot government to legitimate claims of maritime zones under international law. ${ }^{94}$

89 Green (n 76) $107 \mathrm{ff}$.

90 For an inclusive list regarding the criteria of consistency see, Green (n 76) 107-108, note 1.

91 Information note by Turkey, concerning its objection to the Agreement between the Republic of Cyprus and the Arab Republic of Egypt on the Delimitation of the Exclusive Economic Zone, 17 February 2003 in UN Law of the Sea Bulletin 54 (n 21) 127

92 Continental Shelf Law, Law No. 8 of 5 April 1974 (n 15).

93 Geographical coordinates showing baselines for measuring the breadth of the territorial sea, Legislation - United Nations Division for Ocean Affairs and the Law of the Sea Office of Legal Affairs <https://www.un.org/Depts/los/ LEGISLATIONANDTREATIES/PDFFILES/CYP_1993_Coordinates.pdf>accessed 14 August 2019.

94 In this regard, it might be beneficial to compare two cases where the practices of the relevant states were examined in terms of consistency by the ICJ and the Inter-American Commission on Human Rights. In the above-mentioned Anglo-Norwegian Fisheries Case, United Kingdom strived to prove that Norway had not followed the principles of delimitation which it had described as its traditional system of delimitation in a consistent manner and referred to some documents during the hearing. In its decision the ICJ stated that: '...too much importance need not be attached to the few uncertainties or contradictions, real or apparent, which the United Kingdom Government claims to have discovered in Norwegian practice. 'Moreover, in the eyes of the Court, it was 'impossible to rely upon a few words taken from a single note to draw the conclusion that the Norwegian Government had abandoned a position which its earlier official documents had clearly indicated.' Fisheries case (n 81) 138; In the case Michael Domingues v. United States, Inter-American Commission on Human Rights assessed the stance of the United States as objector to the customary international law prohibiting the juvenile execution. There had definitely been a pattern of objection prior to 2002, given the fact that detailed evidence of repeated objection on behalf of the United States was provided since the first juvenile execution in the United States recorded in 1642. However, while it was difficult to argue that the objections of the United States were anything other than persistent, Green states that a number of authors have concluded that its objections were not sufficiently consistent in order to gain exemption from the prohibition on juvenile death penalty. In addition to fact that the State Department explicitly denied that the United States intended to reserve a right to execute juvenile offenders on more than one occasion, in a number of instances, its domestic case law also constituted evidence of the inconsistent practice it followed regarding the application of the juvenile death penalty. Furthermore, it was evident that the United States' wider international engagement with the prohibition was at odds with its dissenting stance since it had ratified the Fourth Geneva Convention, signed the American Convention on Human Rights and the Convention on the Rights of the Child without any objection to the norm and even had jointly sponsored 


\section{B. Delimitation of Maritime Boundaries Under International Law}

Whether or not Turkey tacitly recognized the entitlement of the GCASC to maritime zones, as stated by the Turkish Ministry of Foreign Affairs on multiple occasions, entitlement of islands to maritime areas and their effect to maritime boundary delimitation are two different issues. ${ }^{95}$ However intertwined and complementary these two may be, the two concepts still must be clearly distinguished. ${ }^{96}$ With the words of Antunes and Becker-Weinberg:

"Entitlement concerns maritime zones and their limits and is "unilateral" in nature; whereas delimitation relates to maritime boundaries and their delimitation and involves a "bilateral" ("multilateral") process. The latter aims at "discovering" - through application of international law, if effected by a court - a line separating the maritime zones of two (or more) states, if and where the maritime entitlements of such states overlap. ${ }^{, 97}$

On the other hand, in the case of a dispute of entitlement, the issue does not concern the discovery of the separation line between multiple maritime areas, 'but the possibility itself of claiming the zone'. ${ }^{98}$ This means that the consequence of delimitation is 'a geographical amputation of entitlements' ${ }^{99}$

Since delimitation presupposes an area of overlapping entitlements, as ICJ notes 'any disputed delimitation of a boundary entails some determination of entitlement to the areas to be delimited.' ${ }^{100}$ Nevertheless, entitlements are only the first step in any delimitation. ${ }^{101}$ According to the Turkish perspective, UNCLOS Article 121 merely stipulated the 'legal capacity' of islands in terms of generating maritime zones, put

a United Nations General Assembly Resolution which asserted that Article 6 of the International Covenant on Civil and Political Rights, where the norm is enshrined, sets a minimum for all UN member states, whether or not they had adopted the Covenant. As a result, the Inter-American Commission on Human Rights concluded that the objection of the United States had not been enough consistent to the prohibition of the juvenile death penalty in order to circumvent the customary international law. Michael Domingues v. United States (n 81); Green (n 76) 110.

95 Erciyes 27 May 2019 (n 22); Çagatay Erciyes 'Maritime Issues Maritime Boundary Delimitation, \& Turkey's Off-Shore Activities in the Eastern Mediterranean' (Turkish Ministry of Foreign Affairs, 10 May 2019) <http://www.mfa.gov.tr/site media/html/maritime-delimitation-10-5-2019-presentation.pdf $>$ accessed 14 August 2019.

96 Nuno Marques Antunes and Vasco Becker-Weinberg, 'Entitlement to Maritime Zones and Their Delimitation' in Alex G Oude Elferink, Tore Henriksen and Signe Veierud Busch (eds), Maritime Boundary Delimitation: The Case Law: Is It Consistent and Predictable? (Cambridge University Press 2018) 62, 72.

$97 \quad$ ibid 72.

98 Enrico Milano and Irini Papanicolopulu, 'State responsibility in disputed areas on land and at sea' 71(3) Zeitschrift für Ausländisches Öffentliches Recht und Völkerrecht' [2011] 587, 610.

99 Antunes and Becker-Weinberg (n 96) 73.

100 Aegean Sea Continental Shelf (n 47) [84].

101 'The very essence of the dispute, as formulated in the Application, is thus the entitlement of those Greek islands to a continental shelf, and the delimitation of the boundary is a secondary question to be decided after, and in the light of, the decision upon the first basic question.' Aegean Sea Continental Shelf (n 47) [83]; 'While entitlement and delimitation are two distinct concepts addressed respectively in articles 76 and 83 of the Convention, they are interrelated. The Parties also recognize the interrelationship between entitlement and delimitation. Bangladesh states that " $[\mathrm{t}]$ he Tribunal must answer this question before it can delimit the shelf: does either Party have an entitlement to a continental shelf beyond 200 [nm]?" Likewise, Myanmar observes that "the determination of the entitlements of both States to a continental shelf beyond 200 $[\mathrm{nm}]$ and their respective extent is a prerequisite for any delimitation". Thus the question the Tribunal should first address in the present case is whether the Parties have overlapping entitlements to the continental shelf beyond $200 \mathrm{~nm}$. If not, it would be dealing with a hypothetical question.' Delimitation of the maritime boundary in the Bay of Bengal (Bangladesh/ Myanmar), Judgment, [2012] ITLOS Rep 4, [398]-[399]. 
differently, it simply attached no a priori incapacity for the islands. ${ }^{102}$ Therefore, concerning the maritime areas at the west of the longitude $32^{\circ} 16^{\prime} 18^{\prime \prime}$ Turkey contends that islands in delimitation may be given no weight in the construction of the relevant continental shelf or EEZ delimitation line and this is not related to their entitlement or their potential capacity to create continental shelf or EEZ areas. ${ }^{103}$ According to Turkey, the reason is their distortive effect on equity which will be explained below. ${ }^{104}$

As stated in the Anglo-Norwegian Fisheries case, since the delimitation of sea areas has always an international aspect it cannot be dependent merely upon the will of the coastal State as expressed in its municipal law' and 'the validity of the delimitation with regard to other States depends upon international law. '105 Thus, it might be useful to begin with the explanation of the law that is applicable to the delimitation of the pertinent area.

As mentioned above, Turkey did not sign or accede to UNCLOS. Yet, in the case of Maritime Delimitation and Territorial Questions between Qatar and Bahrain the International Court of Justice recognized that the principles of maritime delimitation enshrined in Articles $74^{106}$ and $83^{107}$ of UNCLOS reflect customary international law. ${ }^{108}$ This view was reiterated by the Court in Territorial and Maritime Dispute (Nicaragua v. Colombia). ${ }^{109}$ Therefore, it can be inferred that Articles 74 and 83,

102 Yüksel İnan and Pınar Gözen Ercan, 'Maritime Relations of Peninsular Turkey: Surrounded by Hostile or Peaceful Water?' in Gözen Ercan P (ed) International Relations, Legality and Global Reach (Palgrave Macmillan 2017) 281, 283.

103 Erciyes 27 May 2019 (n 22); Erciyes 10 May 2019 (n 95); See also for instance, Maritime Delimitation and Territorial Questions between Qatar and Bahrain (n 61) [185] and [219].

104 Erciyes 27 May 2019 (n 22); Erciyes 10 May 2019 (n 95).

105 Fisheries case (n 81) [20].

106 United Nations Convention on the Law of the Sea of 10 December 1982, Article 74. Delimitation of the exclusive economic zone between States with opposite or adjacent coasts 1. The delimitation of the exclusive economic zone between States with opposite or adjacent coasts shall be effected by agreement on the basis of international law, as referred to in Article 38 of the Statute of the International Court of Justice, in order to achieve an equitable solution. 2. If no agreement can be reached within a reasonable period of time, the States concerned shall resort to the procedures provided for in Part XV. 3. Pending agreement as provided for in paragraph 1, the States concerned, in a spirit of understanding and cooperation, shall make every effort to enter into provisional arrangements of a practical nature and, during this transitional period, not to jeopardize or hamper the reaching of the final agreement. Such arrangements shall be without prejudice to the final delimitation. 4. Where there is an agreement in force between the States concerned, questions relating to the delimitation of the exclusive economic zone shall be determined in accordance with the provisions of that agreement.

107 United Nations Convention on the Law of the Sea of 10 December 1982, Article 83. Delimitation of the continental shelf between States with opposite or adjacent coasts 1 . The delimitation of the continental shelf between States with opposite or adjacent coasts shall be effected by agreement on the basis of international law, as referred to in Article 38 of the Statute of the International Court of Justice, in order to achieve an equitable solution. 2. If no agreement can be reached within a reasonable period of time, the States concerned shall resort to the procedures provided for in Part XV. 3. Pending agreement as provided for in paragraph 1, the States concerned, in a spirit of understanding and cooperation, shall make every effort to enter into provisional arrangements of a practical nature and, during this transitional period, not to jeopardize or hamper the reaching of the final agreement. Such arrangements shall be without prejudice to the final delimitation. 4 . Where there is an agreement in force between the States concerned, questions relating to the delimitation of the continental shelf shall be determined in accordance with the provisions of that agreement.

108 Maritime Delimitation and Territorial Questions between Qatar and Bahrain (n 61) [167]ff.

109 Territorial and Maritime Dispute (Nicaragua v. Colombia) (n 62) [139]; See, British Institute of International and Comparative Law, Report on the Obligations of States under Articles 74(3) and 83(3) of UNCLOS in respect of Undelimited Maritime Areas (BIICL 2016) 8. 
leaving aside whether or not the states concerned are parties to UNCLOS, are pertinent to any issue of delimitation. ${ }^{110}$ However in cases where the states concerned are not parties to UNCLOS, the norms applicable would not be Articles 74 and 83 of UNCLOS but rather customary rules of international law having the same content. ${ }^{111}$

By the commencement of negotiations at UNCLOS III in 1974, there existed no law addressing the delimitation of EEZs due to the late introduction of the notion to international law. ${ }^{112}$ The delimitation of continental shelves, on the other hand, was governed by a considerable body of law which had two distinct channels: ${ }^{113}$ Concerning the States who were party to the 1958 Continental Shelf Convention, Article 6 provided that the boundaries between the continental shelves of opposite and adjacent States was to be set via agreements between them. In the absence of agreement, the boundary was to be the equidistance line, every point of which is equidistant from the nearest points of the baselines from which the breadth of the territorial sea of each State is measured (the 'equidistance/special circumstances' rule). The second channel was the rules of customary international law which had been propounded by the ICJ in the North Sea Continental Shelf cases in 1969 and concerned non-parties to the 1958 Continental Shelf Convention. ${ }^{114}$ Even though most maritime boundary agreements known at that time of the North Sea Cases used the equidistant method ${ }^{115}$ the Court found that the method of equidistance did not represent customary international law but instead, it held that:

\footnotetext{
'delimitation is to be effected by agreement in accordance with equitable principles, and taking account of all the relevant circumstances, in such a way as to leave as much as possible to each Party all those parts of the continental shelf that constitute a natural prolongation of its land territory into and under the sea, without encroachment on the natural prolongation of the land territory of the other.'116
}

The judgment of the ICJ in the North Sea, which essentially provided that delimitation processes should be equitable, resulted in the initiation of the Turkish view arguing that 'equitable principles' is the customary rule of delimitation. ${ }^{117}$ Turkey specifically states that in order to ensure the equity of delimitation, the circumstances of the area should be taken into consideration by way of applying equitable principles. ${ }^{118}$ This is, according to Turkey, the rule that in fact reflects the

115 Bölükbaşı (n 32) 301.

116 See, North Sea Continental Shelf (n 49) [88]-[92].

117 İnan and Acer 2004 (n 50) $125 \mathrm{ff}$.

118 ibid.
} 
customary law on the issue of continental shelf delimitation. ${ }^{119}$ Turkey is of the opinion that failing a delimitation agreement, both adjacent and opposite states, should delimit their respective continental shelf 'in accordance with equitable principles by taking into account of all the relevant factors, including, inter alia, the geomorphological and geological structure of the shelf up to the outer limit of the continental margin, and special circumstances such as the general configuration of the respective coasts, the existence of islands, islets or rocks of one state on the continental shelf of the other. ${ }^{120}$ Instead of attaching priority to equidistance or to any solution dictated by judicial precedent or past practice, this rule is designed for application on a case-bycase basis for the purpose of reaching a solution meticulously tailored to the problem in question. ${ }^{121}$

In this context, it is worth mentioning that Turkey sees no contrast between Article 6 of the 1958 Continental Shelf Convention and rules of customary international law governing the delimitation or maritime zones since both of them aim for the ultimate goal of achieving an equitable solution. ${ }^{122}$ In fact, the delimitation cases that occurred after North Sea Continental Shelf and were ruled on before UNCLOS came into force in 1994 are parallel with the longstanding Turkish perspective.

For instance, in the United Kingdom-France Continental Shelf arbitration ${ }^{123}$ after explaining that the existence of special circumstances must be, proprio motu, taken is cognisance and that there is no legal burden of proof in regard to the existence of special circumstances, ${ }^{124}$ the Court of Arbitration found that the equidistance/special circumstances rule enshrined in the 1958 Continental was not distinguishable from the rule of customary international law based upon equitable principles and which

119 ibid.

120 Doc. A/CONF.62/C.2/L.23, Third United Nations Conference on the Law of the Sea, Turkey: draft article on delimitation between States; various aspects involved (26 July August 1974), Official Records of the Third United Nations Conference on the Law of the Sea, vol III, 201.

${ }^{121}$ Merritt R. Blakeslee, 'The distant island problem: the arbitration on the delimitation of the maritime zones around the French collectivité territoriale of Saint Pierre-and-Miquelon' 21(359) Georgia Journal of International \& Comparative Law $359,377$.

122 İnan and Acer (n 50) 126.

${ }^{123}$ Delimitation of the Continental Shelf between the United Kingdom of Great Britain and Northern Ireland, and the French Republic (United Kingdom v. France) 30 June 1977 - 14 March 1978, 18 Reports of International Arbitral Awards 3.

124 In the case, United Kingdom contended that Article 6, paragraph 1 of the 1958 Convention places a burden of proof upon the French Republic as to the existence of any 'special circumstances' and their effect on the method of delimitation to be chosen. The French Republic, on the other hand, in contesting the applicability of Article 6 on the basis of the reservation it made at the time of its adhesion to the Convention and invoking the rules of customary law, opined that the delimitation must be equitable and that the equidistance solely constituted one of the numerous 'methods' which may be chosen in certain circumstances to produce an equitable result. In its award, The Court of Arbitration states as follows: "Article 6, as both the United Kingdom and the French Republic stressed in the pleadings, does not formulate the equidistance principle and "special circumstances" as two separate rules. The rule there stated in each of the two cases is a single one, a combined equidistance-special circumstances rule. This being so, it may be doubted whether, strictly speaking, there is any legal burden of proof in regard to the existence of special circumstances. The fact that the rule is a single rule means that the question whether "another boundary is justified by special circumstances" is an integral part of the rule providing for application of the equidistance principle. As such, although involving matters of fact, that question is always one of law of which, in case of submission to arbitration, the tribunal must itself, proprio motu, take cognisance when applying Article 6.' Delimitation of the Continental Shelf between the United Kingdom of Great Britain and Northern Ireland, and the French Republic (n 123) $67 \mathrm{ff}$. 
attaches no priority to equidistance. ${ }^{125}$ At the relevant part of the decision, the Court of Arbitration stated as follows:

"Article 6 makes the application of the equidistance principle a matter of treaty obligation for Parties to the Convention. But the combined character of the equidistance-special circumstances rule means that the obligation to apply the equidistance principle is always one qualified by the condition "unless another boundary line is justified by special circumstances". Moreover, the travaux préparatoires of Article 6, in the International Law Commission and at the Geneva Conference of 1958, show that this condition was introduced into paragraphs 1 and 2 of the Article because it was recognised that, owing to particular geographical features or configurations, application of the equidistance principle might not infrequently result in an unreasonable or inequitable delimitation of the continental shelf. In short, the rôle of the "special circumstances" condition in Article 6 is to ensure an equitable delimitation; and the combined "equidistance-special circumstances rule", in effect, gives particular expression to a general norm that, failing agreement, the boundary between States abutting on the same continental shelf is to be determined on equitable principles. In addition, Article 6 neither defines "special circumstances" nor lays down the criterion by which it is to be assessed whether any given circumstances justify a boundary line other than the equidistance line. Consequently, even under Article 6 the question whether the use of the equidistance principle or some other method is appropriate for achieving an equitable delimitation is very much a matter of appreciation in the light of the geographical and other circumstances. In other words, even under Article 6 it is the geographical and other circumstances of any given case which indicate and justify the use of the equidistance method as the means of achieving an equitable solution rather than the inherent quality of the method as a legal norm of delimitation.

\section{$[\ldots]$}

In short, whether under customary law or Article 6, it is never a question either of complete or of no freedom of choice as to method; for the appropriateness - the equitable character - of the method is always a function of the particular geographical situation.' ${ }^{26}$

The reasoning of the tribunal in the Anglo-French arbitration was adopted by the ICJ in the case Jan Mayen ${ }^{127}$ which was related to the delimitation of Denmark's and Norway's fishing zones and continental shelves between the east coast of Greenland and the Norwegian island of Jan Mayen. ${ }^{128}$ Alleging that the 1958 Convention favoured the use of the equidistance method, Norway advocated the application of Article 6 to delimit the continental shelf boundary and Denmark argued the opposite. ${ }^{129}$ While Article 6 required the investigation of any 'special circumstances', the customary law required the investigation of the 'relevant circumstances' for its part. After explaining that 'special circumstances' under the Continental Shelf Convention produce the

\footnotetext{
125 Jonathan I. Charney, 'Progress in International Maritime Boundary Delimitation Law' (1994) 88 The American Journal of International Law 227, 244.

126 Delimitation of the Continental Shelf between the United Kingdom of Great Britain and Northern Ireland, and the French Republic (n 123) [70] and [84]

127 Maritime Delimitation in the Area between Greenland and Jan Mayen (Denmark v. Norway) [1993] ICJ Rep 38.

128 Jan Mayen (n 127) [8], [9]; Charney (n 125) 244.

129 ibid.
} 
same result as 'relevant circumstances' used in general international law, ${ }^{130}$ The Court acknowledged that an analysis based on the 1958 Convention will be no different from the one based on the general international law. ${ }^{131}$

\section{The Arrival of UNCLOS}

Proved to be one of the most difficult issues to be agreed on, the delimitation of continental shelf and EEZ boundaries were discussed together at UNCLOS III. At the Conference, most of the participant states divided into two groups: one argued that the starting point for delimitation should be the equidistance line and relied on the 1958 Convention while the other maintained that delimitation should be governed by equitable principles and invoked the North Sea Cases. ${ }^{132}$ Members of the proequidistance principle group ${ }^{133}$ (which included GCASC) favoured the treatment of the equidistance/median line as the standard criterion of delimitation and argued that the equitable principle was too vague and subjective to be an appropriate standard. ${ }^{134}$ GCASC was of the opinion that due to its particular importance to small island states, the median or equitable line should be set as an objective and fair method. ${ }^{135}$

The opposite view, advocated by the supporters of the equitable approach ${ }^{136}$ (including Turkey) objected to the very mention of the equidistance/median line as a standard for delimitation and rejected the elevation of that standard to the status of a basic principle. ${ }^{137}$ Having its support from the North Sea Cases, this group argued that the matter should be governed by equitable principles. ${ }^{138}$

Following the battle royal which went on throughout the Conference with no consensus reached in the relevant Working Group, as a compromise between these two positions, it befell the President of the Conference, Tommy Koh to propose a

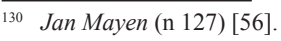

131 Jan Mayen (n 127) [46]; Charney (n 125) 244.

132 British Institute of International and Comparative Law (n 109) 7; For the proposals of various States including Turkey see, Edward McWhinney, Judge Shigeru Oda and the Progressive Development of International Law: Opinions (Declarations, Separate Opinions, Dissents) on the International Court of Justice, 1976-1992 (Martinus Nijhoff 1993) 254ff.

133 Bahamas, Barbados, Canada, Cape Verde, Chile, Columbia, Cyprus, Democratic Yemen, Denmark, Gambia, Greece, Guinea-Bissau, Guyana, Italy, Japan, Kuwait, Malta, Norway, Portugal Spain, Sweden, United Arab Emirates, United Kingdom, Yugoslavia. See, Doc NG7/2/Rev.2 (28 March 1980) in R. Platzöder (ed) Third United Nations Conference on the Law of the Sea: Documents, Vol. IX (Oceana Publications, Inc. 1986) 394.

134 Nugzat Dundua, Delimitation of Maritime Boundaries Between Adjacent States, (United Nations - The Nippon Foundation of Japan Fellowship Programme) (United Nations 2006-2007) 11.

135 Jacovides 25 July 2012 (n 31) 2.

136 Algeria, Argentina, Bangladesh, Benin, Burundi, Congo, France, Iraq, Ireland, Ivory Coast, Kenya, Liberia, Libya, Madagascar, Maldives, Mali, Mauritania, Morocco, Nicaragua, Pakistan, Papua New Guinea, Poland, Romania, Senegal, Syrian Arab Republic, Somalia, Turkey, Venezuela and Vietnam. See, Doc NG7/10/Rev.1 (25 March 1980) in Platzöder (n 133) 403.

137 Dundua (n 134) 11.

138 Jacovides 25 July 2012 (n 31) 2
} 
formula, based on 'constructive ambiguity'"139 and 'at a high level of generality' 140 which provides 'little real guidance to States as to the method(s) that could or should be used to delimit a boundary' ${ }^{141}$ and 'invests the Court and tribunals with a wide power of discretion in addressing delimitation disputes' ${ }^{142}$.

The resulting provisions of UNCLOS, namely Article 74 and Article 83 which deal with the delimitation of EEZs and continental shelves respectively, are indistinguishable except for the fact that the words 'exclusive economic zone' that are used in Article 74 are replaced by 'continental shelf' in Article 83. Authors state that the absence ${ }^{143}$ of the terms ${ }^{144}$ 'equidistance' and 'median line' in the wording of these two articles was a reflection of the shortcomings of the equidistance method which resulted in its undoing, even with the elasticity that the notion of special circumstances added to it. ${ }^{145}$ Since North Sea Cases, the privileged role of the equidistance method had been strongly objected and diminished. ${ }^{146}$ The ICJ and the arbitral tribunals consistently had maintained the fundamental view that the method of equidistance was neither the preferred method of delimitation nor a compulsory rule of customary international law. ${ }^{147}$ Considered as a method which in some cases may result in inequity, in the majority of cases, international tribunals had been of the opinion that equidistance was nothing more than a method amongst others. ${ }^{148}$ In

139 ibid.

140 British Institute of International and Comparative Law (n 109) 7.

141 ibid.

142 Dundua (n 134) 13.

143 In the Informal composite negotiating text both Article 74 and 83 used the wording "the median or equidistance line" as follows: Article 74. Delimitation of the exclusive economic zone between adjacent or opposite States 1 . The delimitation of the exclusive economic zone between adjacent or opposite States shall be effected by agreement in accordance with equitable principles, employing, where appropriats, the median or equidistance line, and taking account of all the relevant circumstances. Article 83. Delimitation of the continental shelf between adjacent or opposite States 1 . The delimitation of the continental shelf between adjacent or opposite States shall be effected by agreement in accordance with equitable principles, employing, where appropriate, the median or equidistance line, and taking account of all the relevant circumstances. Doc A/CONF.62/WP.10 Third United Nations Conference on the Law of the Sea Informal Composite Negotiating Text, Sixth Session Official Records of the Third United Nations Conference on the Law of the Sea, vol XVIII 16, 17.

144 Kastrisios explaines the two terms with the following words 'There is a rational distinction between the terms "median line" and "equidistance line" which was present in the 1958 Convention but absent in the 1982 Convention. Median line (present in the 1982 convention) is defined as the line every point of which is at an equal distance from the nearest points on two opposite baselines, while equidistant line (absent in the convention of 1982) is defined as that at equal distance from two adjacent baselines. Technically speaking, the distinction between the two definitions seems geometrically correct since a median line presupposes that it lies in the middle of the other two geometric features while the equidistance line is apparently not in the middle and is therefore not a median.' Christos Kastrisios, Methods of Maritime Outer Limits Delimitation (Hellenic Naval Academy 2014) at E-16 <http://nausivios.snd.edu.gr/docs/2014E1.pdf $>$ accessed 14 August 2019; See also Aaron L. Shalowitz, Shore and Sea Boundaries, Vol. 1, (Washington: U.S. Dept. of Commerce, Publication 10-1, U.S. Govt. Printing Office 1962) 231.

145 Dundua (n 134) 16; Leonard Legault and Blair Hankey, 'Method, Oppositeness and Adjacency, and Proportionality in Maritime Boundary Delimitations' in Jonathan I. Charney and Lewis M. Alexander (eds), International Maritime Boundaries (Martinus Nijhoff 1993) 201, 204.

146 Barbara Kwiatkowska, 'Equitable maritime delimitation - A legal perspective' (1988) 3(4) International Journal of Estuarine And Coastal Law 287, 300.

147 Bölükbaşı (n 32) 301.

148 For instance, in addition to the cases mentioned above, in its judgment concerning the delimitation of the continental shelf between Tunisia and Libyan Arab Jamahiriya, the ICJ examined the developments since the 1969 North Sea Continental Shelf Cases and found that the application of the equidistance method could not, in the particular circumstances of the case, lead to an equitable result. The Court noted that "Treaty practice, as well as the history of Article 83 of the draft convention 
addition to its demolishing, the opposition that the method faced at the UNCLOS III was so strong that the words 'equidistance' and 'median line' were removed from the wording of Article 74 and 83 and remained only in Article 15 which deals with the delimitation of the territorial sea. ${ }^{149}$ The vanishment process of the aforementioned terms was described as "a holy war against equidistance" by Professor Weil. ${ }^{150}$

Indeed, the objection of the Turkish Delegation to the equidistance method at the 1982 Conference fits this description. The hard fight of Turkey to protest the provisions that were eventually included in the UNCLOS were considered by a Greek author a 'near obsession with the notions of equity and of special circumstances in all their various forms. ${ }^{151}$ Since the beginning of the Conference, Turkey's stance has been that Articles 74 and 83 should be interpreted in the light of developments in international law with regard to the delimitation of the continental shelf or economic zone, and particularly in view of the tendency of the Courts to take into consideration the particular relevant factors or circumstances of the area to achieve an equitable solution. During the Plenary Meeting 189, this stance was explained by Ambassador Kirca by citing the continental shelf case between Tunisia and the Libyan Arab Jamahiriya as follows:

'The only concrete guidance provided in those articles is that the ultimate goal of the negotiations between the parties should be "to achieve an equitable solution". The Court's judgment of 1982 on the continental shelf case between Tunisia and the Libyan Arab Jamahiriya clarifies the concept of "equitable solution" as follows:

"The result of the application of equitable principles must be equitable ... It is, however, the result which is predominant. The principles are subordinate to the goal."

The Court also indicates how, in practice, the equitable principles should be applied. The application of equitable principles involves, according to the Court, action "to balance up the various considerations which it [the Court] regards as relevant in order to produce an equitable result."

The Court then examines the relevant circumstances which are to be taken into account in the application of equitable principles. In the Court's opinion, "It is virtually impossible to achieve an equitable solution in any delimitation without taking into account the particular relevant circumstances of the area."

on the Law of the Sea, leads to the conclusion that equidistance may be applied if it leads to an equitable solution; if not, other methods should be employed." Continental Shelf (Tunisia/Libyan Arab Jamahiriya), Judgment, [1982] ICJ Rep 18, [109]

149 In other words, as Lee states 'It can be said that the "Equitable Principles Group", which had given emphasis to achieving an equitable solution, succeeded in deleting the term 'equidistance', in Articles 74(1) and 83(1) of the 1982 UNCLOS.' Ki Beom Lee, The Demise of Equitable Principles and the Rise of Relevant Circumstances in Maritime Boundary Delimitation (Submitted for the Degree of Ph.D. School of Law The University of Edinburgh 2012) $29<\mathrm{https} / /$ www.era.lib.ed.ac.uk/ bitstream/handle/1842/7576/Lee2012.pdf? sequence=2\&isAllowed=y $>$ accessed 14 August 2019.

150 Prosper Weil, The law of maritime delimitation-reflections (Grotius Publications Ltd. 1989) 205; Dundua (n 134) 16; Kastrisios (n 145) at E-16.

151 Krateros M. Ioannou, The Greek Territorial Sea, in Theodore C. Kariotis (ed) Greece and the Law of the Sea (Kluwer Law International 1997) 115, 127; See also, Jon M. Van Dyke, 'An Analysis of the Aegean Disputes under International Law' (2005) 36(1) Ocean Development \& International Law 63, 87ff. 
It is thus clear that the term "equitable solution" in articles 74 and 83 comprises the idea of applying equitable principles by taking into account all relevant circumstances with a view to arriving at an equitable result. ${ }^{152}$

\section{Assimilation of the Two Rules and Contemporary Approach of the International Courts to the Delimitation of Continental Shelves and Exclusive Economic Zones}

As the ICJ concluded that the equidistance/special circumstances rule enshrined in Article 6 of the 1958 Geneva Convention leads to identical results with the equitable principles/relevant circumstances rule of customary international law, ${ }^{153}$ the Court has stopped making efforts to clarify the meaning of equitable principles since the Jan Mayen case. ${ }^{154}$ Therefore, in contrast to the earlier case law which had denied the use of the equidistance method as an obligatory standard and intended to ascertain the meaning of equitable principles, with its decision Jan Mayen, the Court repudiated the substantial difference between the two rules and at least "justified the "provisional" use of the equidistance method'. ${ }^{155}$

Subsequent developments to the Jan Mayen case created what may be referred to as 'the two-step approach' which sets the equidistance line as an initial point of delimitation and then takes into account the factors calling for the adjustment or shifting of the provisional equidistance line for the purpose of achieving an equitable result. ${ }^{156}$ Leaving behind the term 'special circumstances', this method has been called 'equidistance/relevant circumstances rule' by international courts and tribunals since the 2002 Land and Maritime Boundary (Cameroon/Nigeria) case ${ }^{157}$ and was explained in the Arbitration regarding the delimitation of the maritime boundary between Guyana and Suriname ${ }^{158}$ as follows:

'Articles 74 and 83 of the Convention require that the Tribunal achieve an "equitable solution". The case law of the International court of Justice and the arbitral jurisprudence as well as State practice are at one in holding that the delimitation process should, in appropriate cases, begin by positing a provisional equidistance line which may be adjusted in the light of relevant circumstances in order to achieve an equitable solution. ${ }^{159}$

\footnotetext{
152 189th Plenary meeting (8 December 1982) (n 34) 77. Kirca also mentioned that the remarks he made concerning the provisions on the delimitation of exclusive economic zones and continental shelves should also be applicable by analogy to the delimitation of contiguous zones on which the Convention is silent.

153 See supra, section 'The Assimilation of the Two Rules and the Contemporary Approach of the ICJ and the International Tribunals regarding the delimitation of Continental Shelves and Exclusive Economic Zones'.

154 Lee (n 150) 30.

155 ibid 31.

156 Thomas Cottier, Equitable Principles of Maritime Boundary Delimitation: The Quest for Distributive Justice in International Law (Cambridge University Press 2015) 413.

157 Land and Maritime Boundary between Cameroon and Nigeria (Cameroon v. Nigeria: Equatorial Guinea intervening), Judgment, [2002] ICJ Rep 303; Lee (n 150) 31 and note 40 at 10.

158 Award in the arbitration regarding the delimitation of the maritime boundary between Guyana and Suriname, Award of 17 September 2007, 30 Reports of International Arbitral Awards 1.

159 Award in the arbitration regarding the delimitation of the maritime boundary between Guyana and Suriname, (n 159) [342]
} 
In addition to Jan Mayen, Cameroon/Nigeria and Guyana/Suriname this approach has been put into practice in the relevant parts of judgments and awards such as Eritrea/ Yemen, ${ }^{160}$ Qatar/Bahrain, ${ }^{161}$ and Barbados/Trinidad and Tobago. ${ }^{162}$ In 2009, the ICJ added a third step to the approach with its decision on the case Maritime Delimitation in the Black Sea ${ }^{163}$ when the Court ensured the avoidance of a disproportionate overall result via its final check. ${ }^{164}$ Including the third stage it explicitly added, the Court explained this three-step approach with the following words in the Black Sea case:

'In keeping with its settled jurisprudence on maritime delimitation, the first stage of the Court's approach is to establish the provisional equidistance line. At this initial stage of the construction of the provisional equidistance line the Court is not yet concerned with any relevant circumstances that may obtain and the line is plotted on strictly geometrical criteria on the basis of objective data.

\section{$[\ldots]$}

The course of the final line should result in an equitable solution (Articles 74 and 83 of UNCLOS). Therefore, the Court will at the next, second stage consider whether there are factors calling for the adjustment or shifting of the provisional equidistance line in order to achieve an equitable result [...]. The Court has also made clear that when the line to be drawn covers several zones of coincident jurisdictions, 'the so-called equitable principles/relevant circumstances method may usefully be applied, as in these maritime zones this method is also suited to achieving an equitable result' $[\ldots]$.

\section{$[\ldots]$}

Finally, and at a third stage, the Court will verify that the line (a provisional equidistance line which may or may not have been adjusted by taking into account the relevant circumstances) does not, as it stands, lead to an inequitable result by reason of any marked disproportion between the ratio of the respective coastal lengths and the ratio between the relevant maritime area of each State by reference to the delimitation line [...]. A final check for an equitable outcome entails a confirmation that no great disproportionality of maritime areas is evident by comparison to the ratio of coastal lengths.' ${ }^{165}$

Being said to 'render great service to the judges by offering stability and predictability', ${ }^{166}$ frequent employment of the three-stage equidistance/relevantcircumstances method by ICJ and the international tribunals might give the impression

\footnotetext{
160 Award of the Arbitral Tribunal in the second stage of the proceedings between Eritrea and Yemen (Maritime Delimitation) Decision of 17 December 1999, 22 Reports of International Arbitral Awards 335.

161 Maritime Delimitation and Territorial Questions between Qatar and Bahrain (n 61).

162 Arbitration between Barbados and the Republic of Trinidad and Tobago, relating to the delimitation of the exclusive economic zone and the continental shelf between them, Decision of 11 April 2006, 27 Reports of International Arbitral Awards 147.

163 Maritime Delimitation in the Black Sea (Romania v. Ukraine), Judgment [2009] ICJ 61 Reports.

164 Cottier (n 157) 413.

165 Maritime Delimitation in the Black Sea (n 164) [118], [120] and [122].

166 Tafsir Malick Ndiaye, 'The judge, maritime delimitation and the grey areas' (2015) 55(4) Indian Journal of International Law 493, 506; International Court of Justice, Déclarations du président, Discours de S. Exc. M. Peter Tomka, Président De La Cour Internatıonale De Justice, Devant La Sixième Commission de L'assemblée Générale le 2 Novembre 2012, 13.
} 
that there has been a departure from equity towards a strict rule-based approach based upon equidistance. ${ }^{167}$ However, even though the attempts to clarify the meaning of equitable principles seems to have rapidly waned, it should be mentioned that the role of equity and equitable principles in the field of maritime delimitation has not disappeared. ${ }^{168}$

Following the Jan Mayen case, the ICJ in both the Maritime Delimitation and Territorial Questions between Qatar and Bahrain and Land and Maritime Boundary between Cameroon and Nigeria mentioned that the 'equidistance/special circumstances' rule is closely interrelated with and 'very similar' to the rule of 'equitable principles/relevant circumstances'. ${ }^{169}$ As an 'hypothesis and a practical starting point', ${ }^{170}$ the establishment of the provisional equidistance line constitutes simply the first step in the delimitation procedure and remains a matter of legal methodology, ${ }^{171}$ instead of a mandatory standard applicable to all instances. ${ }^{172}$ Indeed, the equidistance line is merely a method amongst others which can be called upon in the process of taking into consideration all the relevant circumstances. ${ }^{173}$ Thus, in the words of the South Korean author Lee, 'the emphasis on the application of equity or equitable principles has also moved towards taking account of all relevant circumstances since the 1993 Greenland/Jan Mayen case, irrespective of the provisional employment of the equidistance method' ${ }^{\prime 74}$ and the Courts in delimitation cases after Jan Mayen have also reached equitable result by taking into consideration all relevant circumstances. ${ }^{175}$ Consequently, whether or not they are applied from the outset, or within a second or third step, the contemporary three-step approach that the case law brought does not render dispensable the role of equitable principles in maritime delimitation since any application of equidistance intrinsically needs to comply with them. ${ }^{176}$

169 " $[\ldots]$ the equidistance/special circumstances rule, which is applicable in particular to the delimitation of the territorial sea, and the equitable principles/relevant circumstances rule, as it has been developed since 1958 in case-law and State practice with regard to the delimitation of the continental shelf and the exclusive economic zone, are closely interrelated" Maritime Delimitation and Territorial Questions between Qatar and Bahrain (n 61) [231]; "[...] in the so-called equitable principles/ relevant circumstances method. This method, which is very similar to the equidistance/special circumstances method applicable in delimitation of the territorial sea, involves first drawing an equidistance line, then considering whether there are factors calling for the adjustment or shifting of that line in order to achieve an "equitable result".' Land and Maritime Boundary between Cameroon and Nigeria (n 158) [288]; Cottier (n 157) 417; Lee (n 150) 30, 31.

170 Arbitration between Barbados and the Republic of Trinidad and Tobago (n 163) [242].

171 Cottier (n 157) 417; See contra, Tanaka (n 2) 148-149.

172 Lee (n 150) 31.

173 ibid.

174 ibid.

175 ibid.

176 Cottier (n 157) 417; In this regard, it is noteworthy to take a look at the words of Kirca at the 189th Plenary Session in 1982: 'It is now generally recognized that equity is the rule of international law to be applied to the delimitation of the continental shelf or the exclusive economic zone. This principle is reflected in the 1969 North Sea continental shelf case, in the Arbitral Tribunal's decision in 1977 on the delimitation of the continental shelf between France and the United Kingdom and in the case concerning the continental shelf between Tunisia and the Libyan Arab Jamahiriya, of 1982. In the North
} 
As to the dispute concerning the maritime areas at the west of the longitude $32^{\circ}$ 16 ' 18 ', one of the main disagreements between Turkey and GCASC is the question whether there exist special/relevant circumstances in the area that are subject to the overlapping claims. GCASC contends that in the absence of a delimitation agreement, only claims up to the median line are acceptable on the grounds that there are no special/relevant circumstances at the west of the Island and the provisional equidistance line in this case is clearly equitable. ${ }^{177}$ Turkey, on the other hand, opines that the Island of Cyprus cannot generate full EEZ and/or CS at the west of the Island under international law since the area possesses both geographical (such as configuration of the coasts and basepoints) and non-geographical (such as historical rights and the presence of third states) special/relevant circumstances. ${ }^{178}$ Above all, Turkey believes that the median line is inacceptable given the sustained trend in international jurisprudence towards giving islands a reduced effect in maritime boundary delimitation and the principle of proportionality. ${ }^{179}$

Indeed, islands have been granted relatively less power in every major judicial or arbitral decision in terms of maritime boundary delimitation. ${ }^{180}$ As a general category of geographic feature probable to prove problematical from the earliest stages of maritime delimitation discussions, ${ }^{181}$ the existence of islands is quite often set forth as a relevant circumstance that may result in the adjustment of any provisional equidistance line. ${ }^{182}$ In its presentation entitled 'Turkey's Off-Shore Activities In The Eastern Mediterranean \& Maritime Boundary Delimitation In International Law'183 dated 27 May 2019, the Turkish Ministry of Foreign Affairs provides numerous examples of jurisprudence and state practice where islands have been granted a reduced effect or even completely disregarded in maritime delimitation. These examples include but are not limited to the Scilly and Channel Islands in the

\footnotetext{
Sea continental shelf case of 1969, the Court provides that "in this field it [equity] is precisely a rule of law that calls for the application of equitable principles." In the Tunisia-Libyan Arab Jamahiriya case, the Court stipulates that "the legal concept of equity is a general principle directly applicable as law." Furthermore, the Court rules: "The principles and rules of international law applicable for the delimitation ... are as follows: The delimitation is to be effected in accordance with equitable principles and taking account of all relevant circumstances." Therefore, it is to be concluded that the words "on the basis of international law" do not add any new element to articles 74 and 83 since, in the delimitation context, equity or equitable solution, which already exists in the articles, is the rule of law. On the other hand, the reference to international law does not leave the door open to introducing the equidistance method or the median-line method as a rule of international law, nor does it lead to a presumption in favour of equidistance or median line in relation to other methods. In the TunisiaLibyan Arab Jamahiriya case, the Court provides that "Treaty practice, as well as the history of article 83 of the draft convention on the law of the sea, leads to the conclusion that equidistance may be applied if it leads to an equitable solution. If not, other methods should be employed . . . since equidistance is not, in the view of the Court, either a mandatory legal principle or a method having some privileged status in relation to other methods." The same thinking is embodied in the North Sea continental shelf case and in the decision of the Court of Arbitration on the delimitation of the continental shelf between France and the United Kingdom.' 189th Plenary meeting (8 December 1982) (n 34) 77.

177 Tzionis 7 June 2019 (n 28).

178 Erciyes 27 May 2019 (n 22); Erciyes 10 May 2019 (n 95).

179 Erciyes 27 May 2019 (n 22); Erciyes 10 May 2019 (n 95).

180 Van Dyke, (n 152) 88.

181 Hiran Wasantha Jayewardene, The Regime of Islands in International Law, (Martinus Nijhoff Publishers, 1989) 306ff.

182 ibid 330; Doğru (n 5) $531 \mathrm{ff}$.

183 Erciyes 27 May 2019 (n 22).
} 
Anglo-French Arbitration, ${ }^{184}$ the Kerkennah Islands in the context of the maritime delimitation between Libya and Tunisia ${ }^{185}$ the Maltese islet of Filfla and the role of Malta itself in the delimitation of a continental shelf boundary between Malta and Libya: ${ }^{186}$ French islands St. Pierre and Miquelon in the Canada-France Maritime Boundary Arbitration; ${ }^{187}$ the presence of numerous small insular features including low-tide elevations in the area to be delimited in the Qatar/Bahrain Case; ${ }^{188}$ and the Zubayr and Hanish Groups in the Eritrea/Yemen Arbitration. ${ }^{189}$

Contrarily, the Greek Cypriot Administration of Southern Cyprus, in its presentation entitled 'Recent developments in the continental shelf/EEZ of the Republic of Cyprus' 190 dated 31 May 2019 responds to the Turkish claims contending that 'there is no legal basis for the argument that all islands necessarily "distort" equitable delimitation and should therefore be given diminished effect'. According to GGCASC, the delimitation cases cited by Turkey do not provide metrics as to the delimitation between Turkey and the island of the Cyprus since the majority of these cases concern small and/or isolated islands belonging to continental States or islands that lie on the 'wrong side' of a median line drawn between the main territories of the States concerned. Having its status as an island-State, Cyprus, on the other hand, is not comparable to these islands. ${ }^{191}$ GCASC furthermore states that in the sole case cited by Turkey where an island-State was involved -the continental shelf case between Libyan Arab Jamahiriya and Malta dated $1985^{192}$ - the ICJ, bearing in mind Malta's special status as an island-

184 Other than the 12-nautical-mile territorial sea, the Tribunal gave no effect to Channel Islands which belonged to the UK but were closer to the French coast; hence, located at the "wrong side" of the equidistance line between two mainlands. The Tribunal also granted Britain's Scilly Isles only half-effect" which were located off the coast of the UK near Land's End, Cornwall. Delimitation of the Continental Shelf between the United Kingdom of Great Britain and Northern Ireland, and the French Republic (n 123).

185 Notwithstanding the fact that the main island is 180 square kilometers with a population of 15,000 , the Court granted halfeffect to Kerkennah Islands of Tunisia and gave no effect to the island of Jerba, an inhabited island of considerable size, in analysing the general direction of the coastline. Tunisia/Libyan Arab Jamahiriya (n 149) [129].

186 In light of equitable principles, the Court disregarded the uninhabited tiny island of Filfla which was located $5 \mathrm{~km}$ south of the main island in delimiting the boundary between the two States. Continental Shelf (Libyan Arab Jamahiriya/Malta), Judgment [1985] ICJ Rep 13 [64].

187 In comparison to the Canadian landmasses nearby, the small, yet permanently populated French islands of St. Pierre and Miquelon had reduced capacity to generate maritime areas. Case concerning the delimitation of maritime areas between Canada and France (Canada v. France) Decision of 10 June 1992, 21 Reports of International Arbitral Awards 365.

188 Located near the midway between the Qatar peninsula and the main island of Bahrain, the small, uninhabited, and barren Bahraini islet of Qit'at Jaradah was disregarded by the Court on the grounds that it would not be adequate to permit such a minor maritime feature to cause a disproportionate outcome with regard to the delimitation in the relevant area. Maritime Delimitation and Territorial Questions between Qatar and Bahrain (n 61).

189 Even though it permitted Zuqar and Hanish Groups of Yemen to bend the equidistance line toward Eritrea, the from Yemenese islands were given less effect on the delimitation line than they would have had if they had been continental landmasses. Award of the Arbitral Tribunal in the second stage of the proceedings between Eritrea and Yemen (n 161) [160] and [161]; For the case law of international courts and tribunals regarding the role of islands in delimitation see, Van Dyke (n 152) notes 227-233; Pieter Delmoitie, The Marine Delimitation An evolution of the concept. The effect of islands and low-tide elevations on the marine delimitation (Masterproef van de opleiding 'Master in de rechten' Faculteit Rechtsgeleerdheid Universiteit Gent Academiejaar 2010-2011), 70-99; Clive Howard Schofield, The Trouble with Islands (A Thesis Submitted in Partial Fulfillment of Requirements for the Degree of Master of Laws in The Faculty of Graduate Studies (Law) The University of British Columbia 2009) $165 \mathrm{ff}$

190 Tzionis 31 May 2019 (n 24).

191 ibid.

192 Libyan Arab Jamahiriya/Malta (n 187). 
State, 'adjusted the provisional median line only slightly towards the Maltese coast, thus granting Malta a significant amount of marine area'. ${ }^{193}$

In the aforementioned case, a dispute concerning delimitation of the continental shelf between the Libyan Arab Jamahiriya and the Republic of Malta came before the ICJ on 26 July 1982 after both States had granted petroleum exploration concessions in their continental shelves which raised disputes due to the application of different delimitation principles. Malta was in favour of the strict application of the equidistance principle whereas Libya wanted to adjust the line by taking into account the relevant circumstances. by a special agreement they concluded, the parties requested ICJ to determine the applicable principles of international law for delimitation of continental shelves and their practical application to the instance. The status of Malta as an island-State led to some discussions between the two States as to the treatment of islands in the process of maritime delimitation. Libya contended that no difference should to be taken into account between an island-State and an island that belongs to a continental State; and opined that although the entitlement is no different, an island may be treated in a specific manner in delimitation, as were the Channel Islands in the Anglo-French Arbitration. ${ }^{194}$ Malta, on the contrary, clarified that it did not demand any privileged status for constituting an island-State but did make, in the context of continental shelf delimitation, a distinction between island-States and islands that belong politically to a mainland State. According to Malta's claims, it was merely the latter that the international law grants varying effect, depending on circumstances such as geographical location, size, population or economy. ${ }^{195}$ Notwithstanding Malta's claims, the Court found it necessary that the delimitation line between the areas of continental shelf appertaining respectively to the two Parties, be adjusted so as to lie closer to the coasts of Malta since relevant circumstances indicated that a shift of the boundary line was needed in order to produce an equitable result. ${ }^{196}$ These included, inter alia, the general geographical context in which the islands of Malta appear as a relatively small feature in a semi-enclosed sea; ${ }^{197}$ and secondly, the great disparity in the lengths of the relevant coasts of the two parties. ${ }^{198}$

According to Turkey, the lengths of the relevant coasts should also play a significant role as a relevant/special circumstance in the delimitation of maritime

\footnotetext{
193 Tzionis 31 May 2019 (n 24).

194 Libyan Arab Jamahiriya/Malta (n 187) [52].

195 Libyan Arab Jamahiriya/Malta (n 187). [52].

196 Libyan Arab Jamahiriya/Malta (n 187). [71].

197 As Bölükbaş1 states, with this regard, 'It is widely recognized that, the geographical configuration of the enclosed and semi enclosed seas and the physical disposition of coastal states in such circumstances make the delimitation of maritime zones especially difficult and the presence of features such as islands merely aggravate the problem. Therefore it is generally admitted that islands are "special" or "relevant circumstances" to be duly considered in each delimitation case and that depending on pecularity of a given situation, the considerations of equity would lead to allowing islands diminished effect, despite their capacity and legal entitlement to generate maritime zones as other land territory.' Bölükbaşı (n 32) 367.

198 Libyan Arab Jamahiriya/Malta (n 187) [73].
} 
areas at the west of the longitude $32^{\circ} 16^{\prime} 18^{\prime \prime} .{ }^{199}$ The issue of coastal length has come to have a particular significance in the process of maritime boundary delimitation. ${ }^{200}$ Tribunals take into consideration the lengths of the relevant coasts either in the process of delimitation, or at the end of it in order to verify that the result is equitable. ${ }^{201}$ Following the calculation of the relevant coastal lengths, the ratio between these latter is compared to the ratio of the provisionally delimited water zones. If the maritime areas received by the concerned states do not more or less coincide with their coastal lengths, the delimitation line becomes verified as an adequate boundary. ${ }^{202}$ If the ratio of the received areas are not roughly proportional to the relative lengths of the coastlines, further adjustments or analyses should be thought-out. ${ }^{203}$ 'This is not, however, because the ratio of the parties' relative coastal lengths might require that the determination of the line of delimitation should be based on that ratio', ${ }^{204}$ but because the principle of 'proportionality must be considered in the assessment of factors which enter into the equation leading an equitable result' ${ }^{205}$ In other words, in spite of its significant role, the principle of proportionality does not constitute the sole factor that determines the appropriate delimitation line. As the Tribunal in the Arbitration concerning the delimitation of the EEZ and the continental shelf between Barbados and the Republic of Trinidad and Tobago states:

'In applying proportionality as a relevant circumstance, the decisions of the International Court of Justice [...] kept well away from a purely mathematical application of the relationship between coastal lengths and that proportionality rather has been used as a final check upon the equity of a tentative delimitation to ensure that the result is not tainted by some form of gross disproportion.' ${ }^{206}$

In the case Libya/Malta there was a ratio of 1: 8 in favour of Libya between the coasts facing the region to be limited $^{207}$ and the equidistance line was pushed 18 miles towards the north against Malta. ${ }^{208}$ Concerning the disputed maritime areas at the west of the longitude $32^{\circ} 16^{\prime} 18^{\prime \prime}$ the coasts of Turkey relevant to the said delimitation area extend from Antalya Gazipaşa to Muğla Deveboynu Cap which means an actual coast length of 656 nautical miles and a frontal length which will be considerably longer. The actual length of the relevant coast of GCASC, on the other

\footnotetext{
199 Press Release Regarding the EU General Affairs Council Conclusions on Turkey, (Turkish Ministry of Foreign Affairs, 18 June 2019) <http://www.mfa.gov.tr/no_178_-ab-nin-ulkemiz-ile-ilgili-kararlari-hk.en.mfa > accessed 14 August 2019.

200 Arbitration between Barbados and the Republic of Trinidad and Tobago (n 163) [236].

201 Dundua (n 134) 5.

202 ibid.

${ }^{203}$ Charney (n 125) 241.

204 Arbitration between Barbados and the Republic of Trinidad and Tobago (n 163) [236].

205 Case concerning the delimitation of the maritime boundary between Guinea and Guinea-Bissau Decision of 14 February 1985 (Guinea and Guinea-Bissau) 19 Reports of International Arbitral Awards 149, [118].

206 Arbitration between Barbados and the Republic of Trinidad and Tobago (n 163) [238].

207 Doğru (n 5) 534.

208 Başeren (n 18) 93.
} 
hand, is 32 miles and the frontal length shall be shorter. ${ }^{209}$ Stating that the significant ratio between the frontal lengths constitutes one of the relevant circumstances which must be taken into account in the delimitation between Turkey and the GCASC, Turkish authors mention that even a delimitation in proportion to this ratio would not be sufficient to produce an equitable result given the existence of other relevant circumstances concerning the area. ${ }^{210}$ For instance, Başeren ${ }^{211}$ and Doğru ${ }^{212}$ note that another factor which should have an effect on the shift in the delimitation line in favour of Turkey is the principle of 'non-encroachment' which means that the delimitation should not result in such a manner as to cut off the territorial sea of another State from the high seas or an exclusive economic zone and has been recognized by the ICJ in several cases, including the North Sea Continental Shelf, ${ }^{213}$ Jan Mayen, ${ }^{214}$ Gulf of Fonseca ${ }^{215}$ and St. Pierre and Miquelon. ${ }^{216}$ According to the authors, with the purpose of not restricting access of the relatively much longer coasts of Turkey to the open sea areas, the equidistance line between Turkey and the Island of Cyprus should be shifted towards the east in such a way to open the coasts of Turkey. ${ }^{217}$ Referring to the Guinea and Guinea-Bissau decision of 14 February 1985, authors opine that as constituting the most important ports in the region, particularly the openings of the Antalya and Mersin Ports should not be closed in addition to the crucial maritime route of Suez Canal to which access should not be restricted. ${ }^{218}$

Accordingly, the authors note that taking the above-mentioned issues into consideration and in order to pave the way for the relatively much longer Turkish coastline for access to open seas, in case of a delimitation in the relevant area, the median line should be shifted towards east to $32^{\circ} 16^{\prime} 18^{\prime \prime}$ E longitude. ${ }^{219}$ Başeren states that the delimitation line following the longitude of $32^{\circ} 16^{\prime} 18^{\prime \prime} \mathrm{E}$ towards the south and reaching the equidistance line between the relevant coasts of Turkey and Egypt, should sometimes follow the external borders of the territorial seas of GCASC so as to not intersect the country of the latter. ${ }^{220}$

\footnotetext{
209 ibid; Doğru (n 5) 545.

210 Başeren (n 18) 93; Doğru (n 5) 545ff.

211 Başeren (n 18) 93.

212 Doğru (n 5) 546.

213 North Sea Continental Shelf (n 49) ICJ Rep 3.

214 Jan Mayen (n 127).

215 Land, Island and Maritime Frontier Dispute (El Salvador/Honduras: Nicaragua Intervening), Judgment of 11 September 1992, [1992] ICJ Rep 351.

216 Case concerning the delimitation of maritime areas between Canada and France (n 188).

217 Başeren (n 18) 93; Doğru (n 5) 546.

218 Başeren (n 18) 93; Doğru (n 5) 546; See, Case concerning the delimitation of the maritime boundary between Guinea and Guinea-Bissau (n 207) [121].

219 Bașeren (n 18) 93-94; Doğru (n 5) 546; See, Case concerning the delimitation of the maritime boundary between Guinea and Guinea-Bissau (n 207) [121].

220 Başeren (n 18) 94.
} 
In contrast with these claims, The Greek Cypriot Administration of Southern Cyprus contends that the fact that Turkey has a longer coastline compared to Cyprus does not entail that it must be granted a broader maritime area than it obtains by means of the application of the median line. ${ }^{221}$ In this regard, GCASC puts forward the bilateral delimitation agreement that it concluded with Egypt and states that the agreement is based on the median line notwithstanding the fact that Egypt possesses a longer coastline than Cyprus. ${ }^{222}$ According to the GCASC, the general acceptance by the international community as well as by the countries of the region shows that the median line is 'a proper approach' to the achievement of an equitable delimitation and the delimitation agreements that GCASC signed with Lebanon and Israel based on the median line also reflect this conception. ${ }^{223}$

In this regard, the author finds it important to take a look at the analysis made by Professor Cottier which relies upon a sample of 120 long-distance maritime boundary agreements concluded between 1942 and 1992 and established a total of 132 boundaries. ${ }^{224}$ The sample indicates that median line and equidistance are the most prominent methods invoked, together used in the 33.6 per cent of the agreements, followed by equity or equitable principles with 14.9 per cent. ${ }^{225}$ Furthermore, in almost one-third of all agreements no method was indicated. ${ }^{226}$

Stating that these findings confirm the perception of the ICJ that equidistance does not reflect customary law ${ }^{227}$ and that it constitutes merely a method amongst others ${ }^{228}$

\footnotetext{
221 Tzionis 7 June 2019 (n 28).

222 ibid.

223 Ibid; in this regard it is also important to take a look at the ICJ Judgment of Frontier Dispute where the following statement was made as to the effects of bilateral delimitation agreements on third party states "The Chamber also considers that its jurisdiction is not restricted simply because the end-point of the frontier lies on the frontier of a third State not a party to the proceedings. The rights of the neighbouring State, Niger, are in any event safeguarded by the operation of Article 59 of the Statute of the Court, which provides that "The decision of the Court has no binding force except between the parties and in respect of that particular case". The Parties could at any time have concluded an agreement for the delimitation of their frontier, according to whatever perception they might have had of it, and an agreement of this lund, although legally binding upon them by virtue of the principle pacta sunt servanda, would not be opposable to Niger. A judicial decision, which "is simply an alternative to the direct and friendly settlement" of the dispute between the Parties (P.C.I.J.,Series A, No. 22, p. 13), merely substitutes for the solution stemming directly from their shared intention, the solution arrived at by a court under the mandate which they have given it. In both instances, the solution only has legal and binding effect as between the States which have accepted it, either directly or as a consequence of having accepted the court's jurisdiction to decide the case. Accordingly, on the supposition that the Chamber's judgment specifies a point which it finds to be the easternmost point of the frontier, there would be nothing to prevent Niger from claiming rights, vis-à-vis either of the Parties, to territories lying west of the point identified by the Chamber." Frontier Dispute (Burkina Faso v. Republic of Mali), Judgment [1986] ICJ Rep. 1986554 [46].

224 Cottier (n 157) 691ff (Appendix I) The analysis excluded territorial sea or contiguous zone delimitations as well as the establishment of purely joint or common zones.

225 Professor Cottier explains that the reference to equity or equitable principles have been made 'mostly in the more recen years under review, presumably due to the educational process of UNCLOS III. Between 1978 and 1991, 16 of 53 agreements (30.2 per cent) call upon equity in one form or another. However, recourse to equity is not necessarily meant to exclude delimitation on the basis of equidistance, if this method would produce an equitable result.' Cottier (n 157) 244.

226 Cottier also notes that other methods such as those named in the analysis as 'Parallel of latitude', 'Straight line/Azimuth', 'Perpendicular to coastal line' clearly appear less frequently. Cottier (n 157) 244.

227 See, North Sea Continental Shelf (n 49) [88]-[92].

228 Territorial and Maritime Dispute between Nicaragua and Honduras in the Caribbean Sea (n 217) [272].
} 
which is considered frequently by the Courts as methodological starting point, Cottier notes that without knowing the motivation of the States for using equidistance or median line, the frequent use of these methods in the sample agreements cannot bring about the conclusion that States would apply equidistance as a matter of legal obligations. 229

The surveys contained in the study of Professor Charney who was also a member of the US delegation at the UNCLOS III also suggests a similar finding. Even though Charney mentions that 'if state practice has any influence on the positive law for maritime boundary delimitation, equidistance must have a place', ${ }^{230}$ he explains the difficulty in predicting the exact location of maritime boundaries with the following words:

'In my opinion these global and regional paper and the individual boundary reports support the conclusion that no normative principle of international law has developed that would mandate the specific location of any maritime boundary line. The state practice varies substantially. Due to the unlimited geographic and other circumstances that influence the settlements, no binding rule that would be sufficiently determinative to enable one to predict the location of a maritime boundary with any degree of precision is likely to evolve in the near future. ${ }^{231}$

As Cottier mentions, this view is also shared by the French author Prosper Weil who states that 'while one may safely speak of trends, no clear-cut practice, and $a$ fortiori no customary rule, has emerged as regards the influence that oppositeness and adjacency may have on maritime boundary delimitation'. ${ }^{232}$

Therefore, even though the current trend in state practice shows that the use of the equidistance line is the most preferred method by the states, in addition to the fact that it does not represent the customary law, it is still not easy to accept that it is recognized as 'a proper approach' by the international community to achieve an equitable result in each and every single maritime delimitation without knowing precisely the motivation of the states for choosing equidistance as their method.

\section{Conclusion}

Article 121 of UNCLOS was one of the reasons that constrained Turkey to vote against the Convention since despite Turkey's efforts to withhold some islands from entitlement to the maritime areas, in the end, the Third UN Conference on the Law of the Sea had limited itself merely to the exclusion of those that are rocks and cannot

\footnotetext{
229 Cottier (n 157) 361.

230 Jonathan I. Charney and Lewis M. Alexander (eds), International Maritime Boundaries Volume I (Martinus Nijhoff 1993) xlii.

231 ibid

232 ibid; Prosper Weil, 'Geographic Considerations in Maritime Delimitation' in Jonathan I. Charney and others (eds), International Maritime Boundaries Volume V(Martinus Nijhoff 2005) 115, 126.
} 
sustain human habitation or economic life. Even though Turkey did not sign or accede to UNCLOS, Greek Cypriot Administration claims that Article 121 applies to non-state parties as well on the grounds that the customary characteristic of the rule enshrined in the Article was affirmed by the ICJ in judgments such as Case Concerning Maritime Delimitation and Territorial Questions Between Qatar and Bahrain and the Territorial and Maritime Dispute between Nicaragua and Colombia. While there are authors who state that the rules of customary law reflecting these principles cannot be applied to Turkey since the latter has persistently objected to the Articles of UNCLOS related to the regime of islands, GCASC contends that Turkey had already tacitly recognized the entitlement of the Greek Cypriot government to legitimate claims of maritime zones under international law by not objecting to the Law proclaiming its Continental Shelf and a set of coordinates and a chart depicting its baselines to the United Nations Division for Ocean Affairs and the Law of the Sea in 1993.

Nevertheless, whether or not Turkey tacitly recognized the entitlement of the GCASC to maritime zones, as stated by the Turkish Ministry of Foreign Affairs on multiple occasions, entitlement of islands to maritime areas and their effect to maritime boundary delimitation are two different issues. However intertwined and complementary these two may be, entitlement is a unilateral process which concerns the possibility itself of claiming the zone; whereas delimitation is multilateral and establishes a line separating the maritime zones of two or more states, if and where the maritime entitlements of such states overlap. According to the Turkish perspective, UNCLOS Article 121 merely stipulated the 'legal capacity' of islands in terms of generating maritime zones and it simply attached no a priori incapacity for the islands. Therefore, concerning the maritime areas at the west of the longitude $32^{\circ}$ 16' 18', Turkey contends that islands in delimitation may be given no weight in the construction of the relevant continental shelf or EEZ delimitation line as a result of their distortive effect on equity.

As to the applicable law on the delimitation, the International Court of Justice has recognized that the principles of maritime delimitation enshrined in Articles 74 and 83 of UNCLOS reflect customary international law in cases Maritime Delimitation and Territorial Questions between Qatar and Bahrain and Territorial and Maritime Dispute (Nicaragua v. Colombia). Therefore, customary rules of international law having the same content with these articles are related to the delimitation process between Turkey and GCASC. Article 74 and 83 do not specify a normative rule to be applied in the absence of an agreement or precise factors to be taken into account in delimitation. Stating that the customary rule of delimitation is that of 'equitable principles', Turkey is of the opinion that failing a delimitation agreement, both adjacent and opposite states, should delimit their respective continental shelf in 
accordance with equitable principles by taking into account all the relevant factors. GCASC, on the other hand, contends that in the absence of a delimitation agreement, only claims up to the median line are acceptable.

Even though the ICJ found that the method of equidistance did not represent customary international law in North Sea Cases; in Jan Mayen, the Court repudiated the substantial difference between the equidistance/special circumstances rule and equitable principles/relevant circumstances rule and subsequent developments created what may be referred to as three-stage equidistance/relevant-circumstances method. This latter begins with positing a provisional equidistance line which may be adjusted in the light of relevant circumstances in order to achieve an equitable solution and ends with a final check of proportionality. However, the role of equitable principles in the field of maritime delimitation has not disappeared. The courts on many occasions mentioned that the equidistance line is merely a practical starting point and a method amongst others which can be called upon in the process of taking into consideration all the relevant circumstances. The prominence of the equitable principles has moved towards the consideration of all relevant circumstances irrespective of the provisional utilization of the equidistance line.

As regards the dispute concerning the maritime areas at the west of the longitude $32^{\circ} 16^{\prime} 18^{\prime \prime}$, one of the main disagreements between Turkey and GCASC is the question whether there exist special/relevant circumstances in the area that is subject to the overlapping claims. While GCASC contends that there are no special/relevant circumstances at the west of the Island and the provisional equidistance is equitable, Turkey argues that the area possesses both geographical and non-geographical relevant circumstances. Turkey believes that the median line is inacceptable given the sustained trend in international jurisprudence towards giving islands a reduced effect in maritime boundary delimitation and the principle of proportionality. Taking into consideration the significant ratio between the frontal lengths and the principle of 'non-encroachment', Turkish authors state that in order to pave the way for the relatively much longer Turkish coastline for access to open seas, in case of a delimitation in the relevant area, the median line should be shifted to east to $32^{\circ} 16^{\prime}$ 18 " E longitude.

GCASC on the other hand makes a distinction between island-states and islands that belong politically to a mainland state and contends that the fact that Turkey has a longer coastline compared to Cyprus does not entail that it must be granted a broader maritime area than it obtains by means of the application of the median line. Stating that the general acceptance by the international community as well as by the countries of the region shows that the median line is 'a proper approach' to the achievement of an equitable delimitation, GCASC puts forward the delimitation 
agreements that it signed with Egypt, Lebanon and Israel based on the median line as an indicator of such an acceptance. However, in addition to the fact that equidistance does not represent the customary law and considering that some 40 per cent of the delimitation agreements that the study of Cottier puts forward do not employ the equidistance line, it seems that it is not easy to accept that equidistance is recognized as 'a proper approach' by the international community to achieve an equitable result in each and every single maritime delimitation.

Grant Support: The author received no grant support for this work. 


\section{Bibliography}

A Law To Provide for the Proclamation of the Exclusive Economic Zone by the Republic of Cyprus (Law No. 64(I)/2004) (2nd April 2004) (The Division for Ocean Affairs and the Law of the Sea of the Office of Legal Affairs of the United Nations) <http://www.un.org/depts/los/ LEGISLATIONANDTREATIES/PDFFILES/cyp_2004_eez_proclamation.pdf> accessed 14 August 2019.

Abasheikh O, 'The Validity of the Persistent Offender Rule in International Law' (2004) 9 Coventry Law Journal 40.

Abass A, Complete International Law: Text, Cases, and Materials (2nd edn, Oxford University Press 2014), 48; See generally, Stein (n 68) 457

Act No. 2674 of 20 May 1982, on the Territorial Sea of the Republic of Turkey (The Division for Ocean Affairs and the Law of the Sea of the Office of Legal Affairs of the United Nations) $<$ https://www.un.org/Depts/los/LEGISLATIONANDTREATIES/PDFFILES/TUR_1982_Act. pdf $>$ accessed 14 August 2019.

Antunes NM and Becker-Weinberg V, 'Entitlement to Maritime Zones and Their Delimitation' in Oude Elferink AG, Henriksen T and Busch SV (eds), Maritime Boundary Delimitation: The Case Law: Is It Consistent and Predictable? (Cambridge University Press 2018) 62.

Başeren SH, Dispute Over Eastern Mediterranean Maritime Jurisdiction Areas (2010, Publications of Turkish Marine Research Foundation).

Beckman R and Schofield C, 'Moving Beyond Disputes Over Island Sovereignty: ICJ Decision Sets Stage for Maritime Boundary Delimitation in the Singapore Strait' (2009) 40(1) Ocean Development \& International Law 1, 9.

Blakeslee MR, 'The distant island problem: the arbitration on the delimitation of the maritime zones around the French collectivité territoriale of Saint Pierre-and-Miquelon' 21(359) Georgia Journal of International \& Comparative Law 359,

Bölükbaşı D, Turkey and Greece: The Aegean Disputes: a Unique Case in International Law (Cavendish, 2004).

Bradley CA \& Gulati M, 'Withdrawing from International Custom' (2010) 120 Yale Law Journal 202.

British Institute of International and Comparative Law, Report on the Obligations of States under Articles 74(3) and 83(3) of UNCLOS in respect of Undelimited Maritime Areas (BIICL 2016).

Brownlie I, Principles of Public International Law (2003, 4th edn, Oxford University Press).

Charney JI and Alexander LM (eds), International Maritime Boundaries Volume I (Martinus Nijhoff 1993).

Charney JI, 'Progress in International Maritime Boundary Delimitation Law' (1994) 88 The American Journal of International Law 227.

Charney JI, 'The Persistent Objector Rule and the Development of Customary International Law' (1985) 56 British Yearbook of International Law.

Cottier T, Equitable Principles of Maritime Boundary Delimitation: The Quest for Distributive Justice in International Law (Cambridge University Press 2015) 413.

Continental Shelf Law, Law No. 8 of 5 April 1974 (The Division for Ocean Affairs and the Law of the Sea of the Office of Legal Affairs of the United Nations) <http://www.un.org/depts/los/ LEGISLATIONANDTREATIES/PDFFILES/CYP_1974_Law.pdf $>$.

Crawford J, 'The International Court of Justice and the Law of State Responsibility', in Tams C and Sloan J (eds), The Development of Law by the International Court of Justice (Oxford University Press 2013) 71. 
D'Amato A, The Concept of Custom in International Law (1973 NCROL).

Danilenko GM, Law-Making in the International Community (Brill Nijhoff 1993).

Decree by the Council of Ministers No. 8/4742 (The Division for Ocean Affairs and the Law of the Sea of the Office of Legal Affairs of the United Nations) <https://www.un.org/Depts/los/ LEGISLATIONANDTREATIES/PDFFILES/TUR_1992_Decree.pdf $>$ accessed 14 August 2019.

Decree by the Council of Ministers, No. 86/11264, dated 17 December 1986 (The Division for Ocean Affairs and the Law of the Sea of the Office of Legal Affairs of the United Nations) $<$ https://www.un.org/Depts/los/LEGISLATIONANDTREATIES/PDFFILES/TUR_1986_ Decree.pdf $>$ accessed 14 August 2019.

Demir İ, 'Montrö Boğazlar Sözleşmesi’nin Feshi' (2018) 136 Union of Turkish Bar Associations Review 327, 345; In the context of territorial waters, Melih Başdemir, 'Türkiye'nin Avrupa Birliği Müzakere Sürecinde Yunanistan ile Olan Karasuları Sorunu’ (2007) 6 Güvenlik Stratejileri Dergisi 93.

Delmoitie P, The Marine Delimitation An evolution of the concept. The effect of islands and lowtide elevations on the marine delimitation (Masterproef van de opleiding 'Master in de rechten' Faculteit Rechtsgeleerdheid Universiteit Gent Academiejaar 2010-2011).

Dépôt d'une carte marine et d'une liste de coordonnées géographiques par Chypre (The Division for Ocean Affairs and the Law of the Sea of the Office of Legal Affairs of the United Nations) $<$ http://www.un.org/depts/los/LEGISLATIONANDTREATIES/PDFFILES/mzn_s/mzn6.pdf $>$ accessed 14 August 2019.

Doc A/73/10 International Law Commission, Report of the International Law Commission (Seventieth session 30 April-1 June and 2 July-10 August 2018).

Doc. A/CN.4/682 International Law Commission, Third Report on Identification of Customary International Law (prepared by Special Rapporteur Michael Wood) (Geneva, Sixty-seventh session 27 March 2015).

Doc. A/CONF.62/C.2/L.23, Third United Nations Conference on the Law of the Sea, Turkey: draft article on delimitation between States; various aspects involved (26 July August 1974), Official Records of the Third United Nations Conference on the Law of the Sea, vol III, 201.

Doc A/CONF.62/C.2/L.50 Third United Nations Conference on the Law of the Sea, Greece: draft articles on the regime of islands and other related matters (9 August 1974), Official Records of the Third United Nations Conference on the Law of the Sea, vol III.

Doc A/CONF.62/C.2/L.55 Third United Nations Conference on the Law of the Sea, Turkey: draft articles on the regime of islands (13 August 1974), Official Records of the Third United Nations Conference on the Law of the Sea, vol III.

Doc A/CONF.62/SR.160 Third United Nations Conference on the Law of the Sea 160th Plenary meeting (30 March 1982), Official Records of the Third United Nations Conference on the Law of the Sea, vol XVI, 27.

Doc A/CONF.62/SR.169 Third United Nations Conference on the Law of the Sea 169th Plenary meeting (15 April 1982), Official Records of the Third United Nations Conference on the Law of the Sea, vol XVII.

Doc A/CONF.62/SR.189 Third United Nations Conference on the Law of the Sea 189th Plenary meeting (8 December 1982), Official Records of the Third United Nations Conference on the Law of the Sea, vol XVII.

Doc A/CONF.62/WP.10 Third United Nations Conference on the Law of the Sea Informal Composite Negotiating Text, Sixth Session Official Records of the Third United Nations Conference on the Law of the Sea, vol XVIII. 
Doc C.2/Informal Meeting/21 of 28 April 1978.

Doc NG7/2/Rev.2 (28 March 1980) in Platzöder R (ed) Third United Nations Conference on the Law of the Sea: Documents, Vol. IX (Oceana Publications, Inc. 1986) 394

Doc NG7/10/Rev.1 (25 March 1980) in Platzöder R (ed) Third United Nations Conference on the Law of the Sea: Documents, Vol. IX (Oceana Publications, Inc. 1986) 403.

Doğru S, 'Doğu Akdeniz'de Hidrokarbon Kaynakları Ve Uluslararası Hukuka Göre Bölgedeki Kıta Sahanlığı Ve Münhasır Ekonomik Bölge Alanlarının Sınırlandırılması' (2015) 119 Union of Turkish Bar Associations Review 503, 544ff.

Dumberry P, 'Incoherent and Ineffective: The Concept of Persistent Objector Revisited' (2010) 59 International and Comparative Law Quarterly 779.

Dumberry P, 'The Last Citadel! Can a State Claim the Status of Persistent Objector to Prevent the Application of a Rule of Customary International Law in Investor-State Arbitration?' (2010) 23 Leiden Journal of International Law 379.

Dundua N, Delimitation of Maritime Boundaries Between Adjacent States, (United Nations - The Nippon Foundation of Japan Fellowship Programme) (United Nations 2006-2007).

Erciyes Ç 'Maritime Issues Maritime Boundary Delimitation, \& Turkey's Off-Shore Activities in the Eastern Mediterranean' (Turkish Ministry of Foreign Affairs, 10 May 2019) <http://www. mfa.gov.tr/site_media/html/maritime-delimitation-10-5-2019-presentation.pdf $>$ accessed 14 August 2019.

Erciyes Ç 'Turkey's Off-Shore Activities In The Eastern Mediterranean \& Maritime Boundary Delimitation In International Law' (Turkish Ministry of Foreign Affairs, 27 May 2019) <http://www.mfa.gov.tr/site_media/html/maritime-delimitation-27-5-2019presentation.pdf $>$ accessed 14 August 2019.

Eveno VB, 'L'interprétation de l'article 121 de la Convention des Nations Unies sur le droit de la mer par la Cour internationale de Justice' in Angela Del Vecchio, Roberto Virzo (eds), Interpretations of the United Nations Convention on the Law of the Sea by International Courts and Tribunals. (2019 Springer) 59.

Fitzmaurice G, 'The Law and Procedure of the International Court of Justice, 1951-54: General Principles and Sources of Law' (1953) 30 British Yearbook of International Law 1.

Geographical coordinates showing baselines for measuring the breadth of the territorial sea, Legislation - United Nations Division for Ocean Affairs and the Law of the Sea Office of Legal Affairs <https:/www.un.org/Depts/los/LEGISLATIONANDTREATIES/PDFFILES/ CYP_1993_Coordinates.pdf $>$ accessed 14 August 2019.

Green JA, Persistent Objector Rule in International Law (Oxford University Press 2018).

Gündüzler U, 'United Nations Convention on Law of Sea as a Mixed Treaty of EU: A Headache for Turkey?' (2013) 12(2) Ankara Avrupa Çalışmaları Dergisi 61.

Güneş ŞA, 'Birleşmiş Milletler Deniz Hukuku Sözleşmesi ve Deniz Çevresinin Korunması' (2007) 56(1) Ankara Üniversitesi Hukuk Fakültesi Dergisi 1.

Gürdeniz C, 'Jeopolitik, Savunma ve Güvenlik Perspektifinde Türk Deniz Gücü ve 21nci Yüzyıl' (21. Yüzy1l İçin Planlama) <http://21inciyuzyilicinplanlama.org/wp-content/uploads/2016/08/ Cem-Gurdeniz-4.-Sunum.pdf $>$ accessed 14 August 2019.

Gürel A, Mullen F and Tzimitras H, The Cyprus Hydrocarbons Issue: Context, Positions and Future Scenarios, PCC Report 1/2013, (Peace Research Institute Oslo (PRIO) Cyprus Center, 2013) 19.

Henkin L, 'International Law: Politics, Values and Function: General Course on Public International Law’ (1989) 216 Recueil des cours. 
Higgins Rosalyn, 'President, International Court of Justice, Keynote Address at the Sixtieth Anniversary of the International Law Commission (May 19, 2008)' Statements by the President, International Court of Justice.

Information note by Turkey, concerning its objection to the Agreement between the Republic of Cyprus and the Arab Republic of Egypt on the Delimitation of the Exclusive Economic Zone, 17 February 2003 in United Nations Division for Ocean Affairs and the Law of the Sea Office of Legal Affairs, Law of the Sea Bulletin 54 (New York, United Nations, 2004).

International Court of Justice, Déclarations du président, Discours de S. Exc. M. Peter Tomka, Président De La Cour Internatıonale De Justice, Devant La Sixième Commission de L'assemblée Générale le 2 Novembre 2012.

Ioannidis N 'The Continental Shelf Delimitation Agreement Between Turkey and "TRNC" (Blog of the European Journal of International Law [EJIL], 26 May 2014) $<$ https://www.ejiltalk.org/thecontinental-shelf-delimitation-agreement-between-turkey-and-trnc/> accessed 14 August 2019.

Ioannou KM, The Greek Territorial Sea, in Kariotis TC (ed) Greece and the Law of the Sea (Kluwer Law International 1997) 115.

International Law Association Committee on Formation of Customary (General) International Law, Statement of Principles Applicable to the Formation of General Customary International Law (International Law Association, London Conference 2000)

İnan Y and Acer Y, 'The Aegean disputes' in Karaosmanoğlu AL and Taşhan S (eds), The Europeanization of Turkey's security policy: Prospects and pitfalls (Turkish Foreign Policy Institute 2004) 125.

İnan Y and Gözen Ercan P, 'Maritime Relations of Peninsular Turkey: Surrounded by Hostile or Peaceful Water?' in Gözen Ercan P (ed) International Relations, Legality and Global Reach (Palgrave Macmillan 2017) 281.

Jacovides A, 'Current Issues of the Law of the Sea and Their Relevance to Cyprus' (The European Rim Policy and Investment Council, 23 June 2009) <https://erpic.org/wp-content/ uploads/2017/02/andreas-jacovides-current-issues-of-the-law-of-the-sea-and-their-relevanceto-cyprus.pdf $>$ accessed 14 August 2019.

Jacovides A, 'Delimitation Practice in the Eastern Mediterranean' (The European Rim Policy and Investment Council, 25 July 2012) <https://erpic.org/wp-content/uploads/2017/02/delimitationpractice-in-the-eastern-mediterranean.pdf $>$ accessed 14 August 2019.

Jacovides A, International Law and Diplomacy: Selected Writings by Ambassador Andrew Jacovides (Martinus Nijhoff 2011).

Jayewardene HW, The Regime of Islands in International Law, (Martinus Nijhoff Publishers, 1989).

Jennings R and Watts A (eds), Oppenheim's International Law, I: Peace (9th edn, Oxford University Press 1992).

Kastrisios C, Methods of Maritime Outer Limits Delimitation (Hellenic Naval Academy 2014) $<$ http://nausivios.snd.edu.gr/docs/2014E1.pdf $>$ accessed 14 August 2019.

Korkut E, 'Turkey and the International Law of the Sea' (SJD Dissertations 5, The Pennsylvania State University 2017).

Kütükçü MA and Kaya İS, 'Uluslararası Deniz Hukuku Kapsamında Doğu Akdeniz'deki Petrol ve Doğalgaz Kaynakları ile Türkiye'nin Hukuki Durumu’ (2016) 2(1) Journal of Life Sciences 81, $92 \mathrm{ff}$.

Kwiatkowska B and Soons AHA, 'Entitlement to Maritime Areas of Rocks Which Cannot Sustain Human Habitation or Economic Life of Their Own' (1990) 21 Netherlands Yearbook of International Law 139. 
Kwiatkowska B, 'Equitable maritime delimitation - A legal perspective' (1988) 3(4) International Journal of Estuarine And Coastal Law 287.

Lau Holning, 'Rethinking the Persistent Objector Doctrine in International Human Rights Law' (2005-2006) 6 Chicago Journal of International Law 495.

Lee KB, The Demise of Equitable Principles and the Rise of Relevant Circumstances in Maritime Boundary Delimitation (Submitted for the Degree of Ph.D. School of Law The University of Edinburgh 2012) <https:/www.era.lib.ed.ac.uk/bitstream/handle/1842/7576/Lee2012. pdf? sequence $=2 \&$ isAllowed $=\mathrm{y}>$ accessed 14 August 2019 .

Lee LT 'The Law of the Sea Convention and Third States' (1983) 77 The American Journal of International Law 541.

Legault L and Hankey B, 'Method, Oppositeness and Adjacency, and Proportionality in Maritime Boundary Delimitations' in Charney JI and Alexander LM (eds), International Maritime Boundaries (Martinus Nijhoff 1993).

Lepard BD, Customary International Law: A New Theory with Practical Applications (Cambridge University Press 2010).

Leventis Y, 'Projecting for Control of Warm Waters. Turkey's Posturing for Hydrocarbon Hegemony in the Eastern Mediterranean' in Faustmann H, Gürel A and Reichberg GM (eds), The Hydrocarbon Wealth of Cyprus: Equitable Distribution and Regional Politics (Peace Research Institute Oslo (PRIO) Cyprus Center/Friedrich Ebert Foundation 2012) 7.

Lobo de Souza IM, "The Role of State Consent in the Customary Process" (1995) 44 International and Comparative Law Quarterly 521.

McClane JB, 'How Late in the Emergence of a Norm of Customary International Law May a Persistent Objector Object?' (1989) 13 ILSA Journal of International Law 1.

McWhinney Edward, Judge Shigeru Oda and the Progressive Development of International Law: Opinions (Declarations, Separate Opinions, Dissents) on the International Court of Justice, 1976-1992 (Martinus Nijhoff 1993).

Milano E and Papanicolopulu İ, 'State responsibility in disputed areas on land and at sea' 71(3) Zeitschrift für Ausländisches Öffentliches Recht und Völkerrecht' [2011] 587.

Ndiaye TM, 'The judge, maritime delimitation and the grey areas' (2015) 55(4) Indian Journal of International Law 493.

Official Records of the Third United Nations Conference on the Law of the Sea, vol I.

Oude Elferink AG, The law of maritime boundary delimitation: a case study of the Russian Federation (Martinus Nijhoff Publishers 1994) 288ff.

Park Leo, 'The International Court and Rule-Making: Finding Effectiveness' [2018] 39(4) University of Pennsylvania Journal of International Law 1065.

Press Release Regarding the EU General Affairs Council Conclusions on Turkey, (Turkish Ministry of Foreign Affairs, 18 June 2019) <http://www.mfa.gov.tr/no_178_-ab-nin-ulkemiz-ile-ilgilikararlari-hk.en.mfa $>$ accessed 14 August 2019.

Roucounas E, 'Greece and the Law of the Sea', in Tullio Treves, Laura Pineschi (eds), The Law of the Sea (Kluwer, 1997) 225.

Rousseau C, Droit international public, I (Sirey 1970).

Schofield CH, The Trouble with Islands (A Thesis Submitted in Partial Fulfillment of Requirements for the Degree of Master of Laws in The Faculty of Graduate Studies (Law) The University of British Columbia 2009). 
Shalowitz AL, Shore and Sea Boundaries, Vol. 1, (Washington: U.S. Dept. of Commerce, Publication 10-1, U.S. Govt. Printing Office 1962).

Stein T, 'The Approach of the Different Drummer: the Principle of the Persistent Objector in International Law', (1985) 26 Harvard International Law Journal 457.

Tanaka Y, Predictability and Flexibility in the Law of Maritime Delimitation (Hart Publishing 2006).

Territorial Waters Law, 1964 (The Division for Ocean Affairs and the Law of the Sea of the Office of Legal Affairs of the United Nations) <http://www.un.org/depts/los/ LEGISLATIONANDTREATIES/PDFFILES/CYP_1964_Law.pdf $>$ accessed 14 August 2019.

Tesón FR, 'International Obligation and the Theory of Hypothetical Consent', (1990) 15 Yale Journal of International Law 84.

The Exclusive Economic Zone and the Continental Shelf Laws 2004 and 2014 (The Division for Ocean Affairs and the Law of the Sea of the Office of Legal Affairs of the United Nations) $<$ https://www.un.org/Depts/los/LEGISLATIONANDTREATIES/PDFFILES/CYP_EEZ-CS_ Law_2014.pdf $>$ accessed 14 August 2019.

Turkish Ministry of Foreign Affairs, 'Başlica Ege Denizi Sorunları' < http://www.mfa.gov.tr/ baslica-ege-denizi-sorunlari.tr.mfa $>$ accessed 14 August 2019.

Turkish Ministry of Foreign Affairs, 'Comply With The Proposal Or We Will Continue (Article by H.E. Mr. Mevlüt Çavuşoğlu, Minister of Foreign Affairs of the Republic of Turkey, published in 'Kıbrıs Postası" (TRNC) on 14 July 2019)' <http://www.mfa.gov.tr/disisleri-bakani-sayinmevlut-cavusoglu_nun-kibris-postasi-gazetesinde-yayinlanan-makalesi.en.mfa $>$ accessed 14 August 2019.

Turkish Ministry of Foreign Affairs, 'The Outstanding Aegean Issues' <http://www.mfa.gov.tr/ maritime-issues---aegean-sea---the-outstanding-aegean-issues.en.mfa> accessed 14 August 2019.

Tzionis T 'Recent developments in the continental shelf/EEZ of the Republic of Cyprus' (Ministry of Foreign Affairs of Republic of Cyprus, 31 May 2019) <http://www.mfa.gov.cy/mfa/mfa2016.

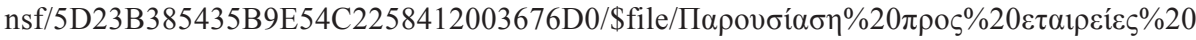
07.06.2019\%20(wfinal).pdf> accessed 14 August 2019.

Tzionis T 'Recent developments in the continental shelf/EEZ of the Republic of Cyprus' (Ministry of Foreign Affairs of Republic of Cyprus, 7 June 2019) <http://www.mfa.gov.cy/mfa/mfa2016.

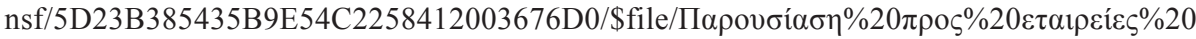
07.06.2019\%20(wfinal).pdf $>$ accessed 14 August 2019.

United Nations Division for Ocean Affairs and the Law of the Sea Office of Legal Affairs, Law of the Sea Bulletin 54 (New York, United Nations, 2004).

United Nations Division for Ocean Affairs and the Law of the Sea Office of Legal Affairs, Law of the Sea Bulletin 57 (New York, United Nations, 2004)

United Nations Division for Ocean Affairs and the Law of the Sea, Régime of Islands: Legislative History of Part VIII (Article 121) of the United Nations convention on the Law of the Sea (1988, United Nations).

Van Dyke JM, ‘An Analysis of the Aegean Disputes under International Law' (2005) 36(1) Ocean Development \& International Law 63.

Verzijl JHW, International Law in Historical Perspective, I (Albertus Willem Sijthoff 1968).

Villiger ME, Customary International Law \& Treaties (2nd edn, Brill Nijhoff 1997).

Weil P, 'Geographic Considerations in Maritime Delimitation' in Charney JI and others (eds), International Maritime Boundaries Volume V (Martinus Nijhoff 2005) 115, 126. 
Weil P, 'Le droit international en quête de son identité: Cours général de droit international public' (1992) 237 Recueil des cours.

Weil P, The law of maritime delimitation-reflections (Grotius Publications Ltd. 1989)

Weil P, 'Towards Relative Normativity in International Law?' (1983) 77 American Journal of International Law 413.

Wolfke K, Custom in Present International Law (2nd edn, Martinus Nijhoff 1993).

Yaycı C, 'Doğu Akdeniz'de Deniz Yetki Alanlarının Paylaşılması Sorunu ve Türkiye' (Bilgesam) 13 $<$ http://www.bilgesam.org/Images/Dokumanlar/0-159-2014040713bs-2012-1-1-70.pdf $>$ accessed 14 August 2019.

Yiallourides C, 'Oil and Gas Development in Disputed Waters under UNCLOS' (2016) 5(1) UCL Journal of Law and Jurisprudence 59.

\section{Cases}

Aegean Sea Continental Shelf (Greece v. Turkey), [1978] ICJ Rep 3.

Arbitration between Barbados and the Republic of Trinidad and Tobago, relating to the delimitation of the exclusive economic zone and the continental shelf between them, Decision of 11 April 2006, 27 Reports of International Arbitral Awards 147.

Award in the arbitration regarding the delimitation of the maritime boundary between Guyana and Suriname, Award of 17 September 2007, 30 Reports of International Arbitral Awards 1.

Award of the Arbitral Tribunal in the second stage of the proceedings between Eritrea and Yemen (Maritime Delimitation) Decision of 17 December 1999, 22 Reports of International Arbitral Awards 335.

Case concerning the delimitation of maritime areas between Canada and France (Canada $v$. France) Decision of 10 June 1992, 21 Reports of International Arbitral Awards 365.

Continental Shelf (Libyan Arab Jamahiriya/Malta), Judgment [1985] ICJ Rep 13.

Continental Shelf (Tunisia/Libyan Arab Jamahiriya), Judgment, [1982] ICJ Rep 18.

Colombian-Peruvian asylum case (Colombia v. Peru) Judgment of November 20th [1950] ICJ Rep 266.

Delimitation of the maritime boundary in the Bay of Bengal (Bangladesh/Myanmar), Judgment, [2012] ITLOS Rep 4.

Delimitation of the Continental Shelf between the United Kingdom of Great Britain and Northern Ireland, and the French Republic (United Kingdom v. France) 30 June 1977 - 14 March 1978, 18 Reports of International Arbitral Awards 3.

Fischbach \& Friedricy case, 10 RIAA 388, (1903, Germany-Venezuela Mixed Claims Commission).

Fisheries case (United Kingdom v. Norway) Judgment of December 18th [1951] ICJ Rep 116.

Frontier Dispute (Burkina Faso v. Republic of Mali), Judgment [1986] ICJ Rep. 1986554.

ICJ Pleadings, Aegean Sea Continental Shelf (Greece v. Turkey).

ICJ Pleadings, Continental Shelf (Libyan Arab Jamahiriya Malta), vol I.

ICJ Pleadings, Fisheries case (United Kingdom v. Norway).

Maritime Delimitation and Territorial Questions between Qatar and Bahrain (Qatar v. Bahrain) [2001] Merits, Judgment, ICJ Rep 40,

Maritime Delimitation in the Area between Greenland and Jan Mayen (Denmark v. Norway) [1993] ICJ Rep 38. 
Maritime Delimitation in the Black Sea (Romania v. Ukraine), Judgment [2009] ICJ 61 Reports.

Michael Domingues v. United States (Case 12.285), Report No. 62/02, Inter-American Commission on Human Rights, Doc. 5 rev. 1 at 913 (2002).

North Sea Continental Shelf (Federal Republic of Germany/Denmark), [1969] ICJ Rep 3.

Roach \& Pinkerton v. United States (Case 9647) Inter-American Commission on Human Rights 147, OEA/ser.LJV/II.71, doc. 9 rev. 1 (1987).

Sabeh El Leil v. France [GC], No. 34869/05, European Court of Human Rights, 29 June 2011.

Siderman de Blake v. Republic of Argentina, United States Court of Appeals for the Ninth Circuit, 965 F.2d 699; 1992 U.S. App..

Territorial and Maritime Dispute (Nicaragua v. Colombia) [2012] Merits, Judgment, ICJ Rep 624,

Land and Maritime Boundary between Cameroon and Nigeria (Cameroon v. Nigeria: Equatorial Guinea intervening), Judgment, [2002] ICJ Rep 303.

Land, Island and Maritime Frontier Dispute (El Salvador/Honduras: Nicaragua Intervening), Judgment of 11 September 1992, [1992] ICJ Rep 351.

Lotus Case (France v Turkey) PCIJ Rep Series A No 10. 